\title{
Changes in hot spring temperature and hydrogeology of the Alpine Fault hanging wall, New Zealand, induced by distal South Island earthquakes
}

\author{
S. C. COX ${ }^{1}$, C. D. MENZIES ${ }^{2}$, R. SUTHERLAND ${ }^{3}$, P. H. DENYS ${ }^{4}$, C. CHAMBERLAIN ${ }^{5}$ AND $^{-}$ \\ D. A. H. TEAGLE ${ }^{1}$ \\ ${ }^{1}$ GNS Science, Dunedin, New Zealand; ${ }^{2}$ Ocean and Earth Science, National Oceanography Centre Southampton, University \\ of Southampton, Southampton, UK; ${ }^{3}$ GNS Science, Lower Hutt, New Zealand; ${ }^{4}$ School of Surveying, University of Otago, \\ Dunedin, New Zealand; ${ }^{5}$ School of Geography, Environment and Earth Sciences, Victoria University of Wellington, \\ Wellington, New Zealand
}

\begin{abstract}
Thermal springs in the Southern Alps, New Zealand, originate through penetration of fluids into a thermal anomaly generated by rapid uplift and exhumation on the Alpine Fault. Copland hot spring (43.629S, 169.946E) is one of the most vigorously flowing, hottest of the springs, discharging strongly effervescent $\mathrm{CO}_{2}$-rich $56-58^{\circ} \mathrm{C}$ water at $6 \pm 1 \mathrm{I} \mathrm{sec}^{-1}$. Shaking from the Mw7.8 Dusky Sound (Fiordland) 2009 and Mw7.1 Darfield (Canterbury) 2010 earthquakes, 350 and $180 \mathrm{~km}$ from the spring, respectively, resulted in a characteristic approximately $1^{\circ} \mathrm{C}$ delayed cooling over 5 days. A decrease in conductivity and increase in $\mathrm{pH}$ were measured following the Mw7.1 Darfield earthquake. Earthquake-induced decreases in $\mathrm{Cl}, \mathrm{Li}, \mathrm{B}, \mathrm{Na}, \mathrm{K}, \mathrm{Sr}$ and $\mathrm{Ba}$ concentrations and an increase in $\mathrm{SO}_{4}$ concentration reflect higher proportions of shallow-circulating meteoric fluid mixing in the subsurface. Shaking at amplitudes of approximately $0.5 \% \mathrm{~g}$ Peak Ground Acceleration (PGA) and/or 0.05-0.10 MPa dynamic stress influences Copland hot spring temperature, which did not respond during the Mw6.3 Christchurch 2011 aftershock or other minor earthquakes. Such thresholds should be exceeded every 1-10 years in the central Southern Alps. The characteristic cooling response at low shaking intensities (MM III-IV) and seismic energy densities (approximately $10^{-1} \mathrm{~J} \mathrm{~m}^{-3}$ ) from intermediate-field distances was independent of variations in spectral frequency, without the need for post-seismic recovery. Observed temperature and fluid chemistry responses are inferred to reflect subtle changes in the fracture permeability of schist mountains adjacent to the spring. Permanent $10^{-7}-10^{-6}$ strains recorded by cGPS reflect opening or generation of fractures, allowing greater quantities of relatively cool near-surface groundwater to mix with upwelling hot water. Active deformation, tectonic and topographic stress in the Alpine Fault hanging wall, where orographic rainfall, uplift and erosion are extreme, make the Southern Alps hydrothermal system particularly susceptible to earthquake-induced transient permeability.
\end{abstract}

Key words: Copland hot spring, earthquake, fluid flow, orogenic geothermal systems, permeability change, Welcome Flat

Received 23 February 2014; accepted 21 June 2014

Corresponding author: Simon C. Cox, GNS Science, Private Bag 1930, Dunedin 9054, New Zealand.

Email: s.cox@gns.cri.nz. Tel: +6434799670. Fax: +6434775232.

Geofluids (2014)

\section{INTRODUCTION}

Earthquake-induced fluid redistribution is of relevance in earth science as it provides an important mechanism for mineral deposit formation (Sibson 2001), and fluids have some control on the strength of faults and the crust (Townend \& Zoback 2000; Faulkner et al. 2010; Saffer
2014). Fluids affect ground strength and shaking behaviour at near-field distances from earthquake epicentres, and transient stresses of seismic waves have potential to interact with fluids and dynamically trigger seismicity at far-field distances (Hill et al. 1993; Brodsky et al. 2000; Husen et al. 2004; Taira et al. 2009). Post-seismic fluid flow can have implications for groundwater supply and quality, 
contaminant transport, underground repository safety and hydrocarbon production (Wang et al. 2013; Wells et al. 2013). Earthquake-induced hydrological responses have potential to provide information on crustal permeability and tectonic processes at spatial and temporal scales that are otherwise difficult to study, helping to highlight that crustal permeability is not a fixed quantity but an ever evolving, dynamic parameter (Wang \& Manga 2010a; Manga et al. 2012).

Given that earthquakes can change groundwater flow, changes in temperature and composition of groundwater are to be expected, but to date there are few comprehensive observations at appropriate epicentral distances and length scales to constrain the various operational mechanisms (e.g. Wang et al. 2004a). At far-field (many fault lengths) distances from an epicentre, static stresses due to the earthquake are small, so sustained changes in groundwater are thought to be the result of processes that can convert (the larger) transient, dynamic strains into medium- to long-term changes in fluid connectivity and flow. Both laboratory and field observations indicate that stresses too small to produce new cracks or pathways are able to change permeability, but laboratory experiments appear to require larger strain amplitudes than observed in natural systems (Manga et al. 2012).

In solid rocks, sustained far-field changes have been mostly attributed to transient changes in permeability caused by local changes in the aperture of fractures and/or mobilisation of small particles into the fluid phase (e.g. Brodsky et al. 2003; Montgomery \& Manga 2003; Shi et al. 2014). Many questions still remain as to the exact pore- and fracture-scale mechanisms that create permeability changes, which can be difficult to decipher in natural systems because of their complexity and the inaccessibility of the subsurface (Manga et al. 2012). However, depending on geological context, different mechanisms of hydrological response to earthquakes should have different characteristic time scales of response and recovery or occur over different length scales (Montgomery \& Manga 2003) or shaking thresholds (Wang \& Manga 2010a,b). By developing empirical catalogues of earthquake-induced changes, it may be possible to elucidate the processes and driving mechanisms by testing hypotheses against scaleappropriate observations (e.g. Rojstaczer et al. 1995; Roeloffs 1996, 1998; Wang et al. 2004b, 2013; Elkhoury et al. 2006, 2011; Liu \& Manga 2009; Manga \& Rowland 2009). Here, we contribute observations from the Copland hot spring in the Southern Alps of New Zealand. This system is a prime candidate for investigations of geothermal responses to seismic activity because this tectonically active region on a plate boundary is host to a dense network of seismometers and continuous and semi-continuous Global Positioning System (cGPS) stations (see Supporting Information for details of the GeoNet seismometer network and
cGPS stations), and the South Island has recently experienced a series of moderate magnitude earthquakes.

Rapid uplift and strong erosion in the Southern Alps of New Zealand has perturbed the thermal structure of the upper crust, leading to geothermal activity and a series of thermal springs in the Pacific plate hanging wall of the Alpine Fault (e.g. Allis et al. 1979; Koons 1987; Allis \& Shi 1995; Beavan et al. 2010a; Sutherland et al. 2012). Elevated topography locally drives circulation and cooling from the surface, whereas rapid uplift and conduction generate buoyancy driven circulation from depth (Koons \& Craw 1991; Koons et al. 1998; Menzies et al. 2014). In this contribution, we document transient changes in the hydrothermal circulation in the shallow crust, observed through characteristic changes in temperature and chemistry of the spring fluids that were induced by seismic shaking from large distal earthquakes. We present observations from continuous monitoring of Copland hot spring temperatures and local rainfall from 2009 to 2011, with less frequent fluid conductivity measurements and chemical analyses spanning periods before and after earthquakes, together with observations from seismometers and cGPS stations. Drawing on surface site observations as a guide, we discuss constraints on the geometry of subsurface flow, nature of observed responses and potential mechanisms for change.

Although we have yet to obtain absolute values of permeability change, our contribution quantifies the low thresholds of shaking needed to produce observable changes in the Southern Alps hydrothermal flow regime. A corollary is that transience in permeability and changes to the flow regime must be relatively frequent, with occurrence and recovery over time scales of years to decades. We also document earthquake-related motion of nearby GPS stations, showing that observed dynamic earthquakeinduced perturbations of the flow regime are associated with small permanent strains at amplitudes of $10^{-7}$ to $10^{-6}$ that are near the lower limit of strains previously known to cause hydrological effects (Manga et al. 2012). We propose that the setting of Copland spring in the mountainous central Southern Alps, on the actively deforming hanging wall of the Alpine Fault plate boundary, is likely to be particularly sensitive to earthquake-induced permeability change and thermal spring response.

\section{SETTING AND CONTEXT}

\section{Tectonics}

The Southern Alps are a topographic expression of oblique $39.7 \pm 0.7 \mathrm{~mm} \mathrm{a}^{-1}$ collision between the Pacific and Australian plates (DeMets et al. 2010) (Fig. 1). The largest late Quaternary fault displacement rates in the region 

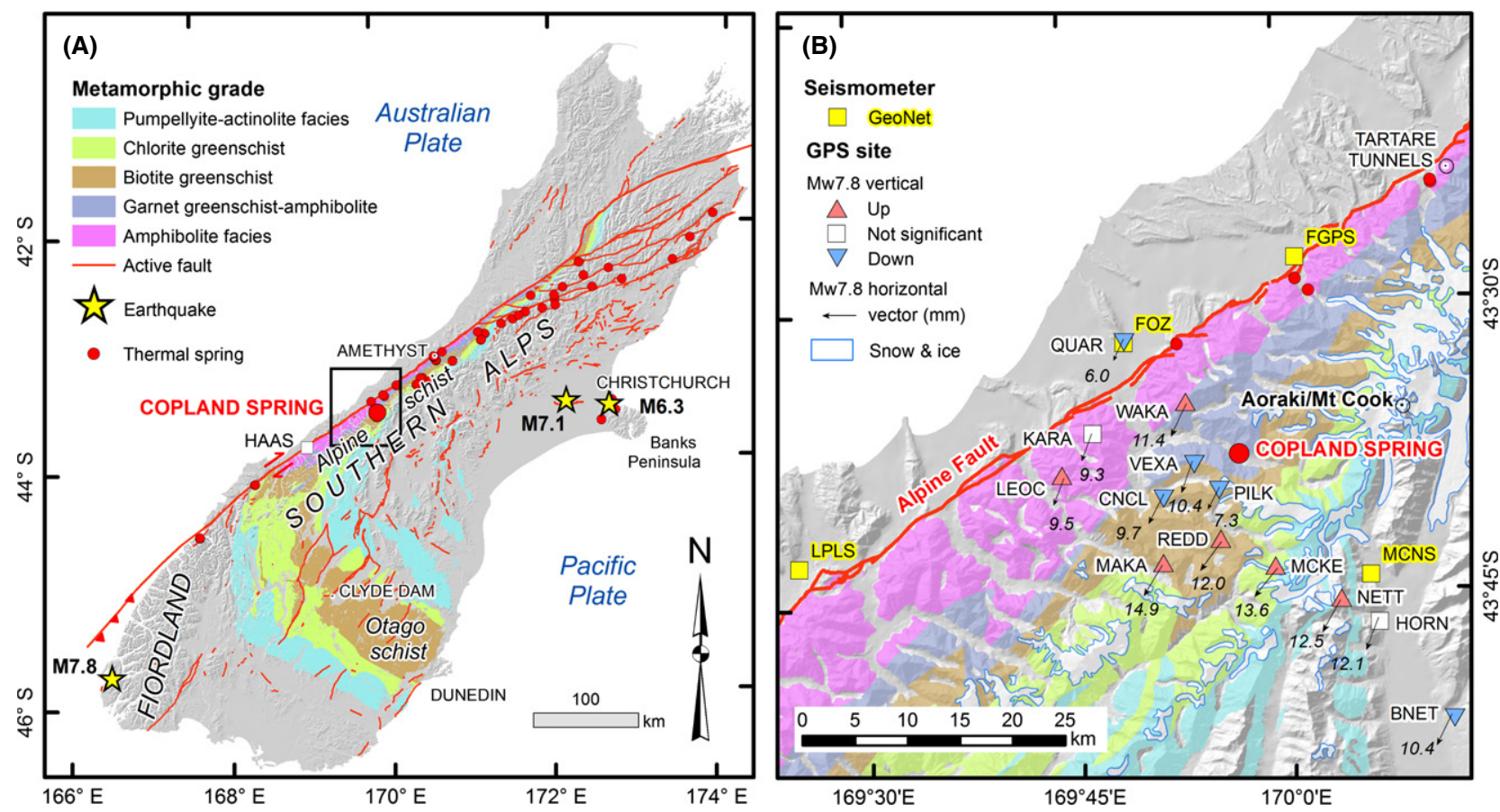

Fig. 1. (A) Map of South Island of New Zealand showing the location of the Copland and other thermal springs, the Alpine Fault and other active faults, and the epicentres of major South Island earthquakes during 2009-2011. The area of the Haast Schist Group, including some sub-greenschist facies semischist, is coloured by metamorphic grade. (B) Detailed map of the central Southern Alps, showing the location of Copland hot spring relative to nearby seismometers (yellow squares) and cGPS stations (triangles and squares). Scaled vectors show horizontal displacement of cGPS stations during the Mw7.8 earthquake, and the triangles are coloured according to the direction of vertical motion (red = upward, blue $=$ downward).

occur on the central Alpine Fault $\left(27 \pm 5 \mathrm{~mm} \mathrm{a}^{-1}\right.$ strikeslip and approximately $10 \mathrm{~mm} \mathrm{a}^{-1}$ dip-slip rates - Norris \& Cooper 2001; Sutherland et al. 2006) along the western side of the alps. Although it has not produced any major earthquakes or measureable creep during New Zealand's $<200$ year written history, paleoseismologic evidence suggests this mature transpressive fault ruptures regularly in great (magnitude $\mathrm{M} \sim 8$ ) earthquakes at recurrence intervals of $329 \pm 68$ years (Sutherland et al. 2007; Berryman et al. 2012). The most recent rupture was approximately $1717 \mathrm{AD}$, so the fault appears to be late in the cycle of stress accumulation that will lead to a future large earthquake (Wells et al. 1999; Howarth et al. 2012). Regional GPS campaigns have revealed that the highest geodetic shear strain rates in New Zealand $\left(>0.3 \mathrm{ppm} \mathrm{a}^{-1}\right)$ are presently occurring within the Southern Alps, above the down-dip extension of the locked uppermost portion of the Alpine Fault (Beavan et al. 2007; Wallace et al. 2007). An array of continuous and semi-continuous GPS stations across the central Southern Alps records approximately $4 \mathrm{~mm} \mathrm{a}^{-1}$ vertical (uplift) rates 10-20 km south-east of the fault (Beavan et al. 2010a). The extent to which this strain is elastic or permanent, and where or when this stored energy may be released, is poorly known. Present-day microseismicity occurs at depths $<15 \mathrm{~km}$ within a seemingly uniform crustal stress field in the Alpine Fault hanging wall (Wallace et al. 2007;
Boese et al. 2012, 2013; Cox et al. 2012a; Townend et al. 2012).

Pacific plate rocks are uplifted in the Alpine Fault hanging wall into the path of the prevailing westerly winds from the Tasman Sea and Southern Ocean, to produce a strongly asymmetric pattern of orographic weather and erosion (Hicks et al. 1996), with heavy $\left(>10 \mathrm{~m} \mathrm{a}^{-1}\right)$ rainfall on the windward western side of the mountains and near arid conditions $\left(<1 \mathrm{~m} \mathrm{a}^{-1}\right)$ in the east (Tait et al. 2006; Cox \& Sutherland 2007). A near-continuous midupper crustal geological section has been exposed by differential uplift and erosion resulting in amphibolite facies Alpine schist adjacent to the Alpine Fault, grading through greenschist facies schist and pumpellyite-actinolite facies semi-schist at the main drainage divide (Main Divide), to prehnite-pumpellyite facies greywacke sandstone in the south-east (Fig. 1; Cox et al. 1997; Cox \& Barrell 2007). The asymmetric rainfall, rapid uplift, erosion and exhumation result in high heat flow, thermal weakening and strong focussing of deformation at or near the Alpine Fault (Koons 1989; Koons et al. 2003; Herman et al. 2009; Sutherland et al. 2012). Topographic-driven infiltration of meteoric waters through fractures intersects the shallow thermal anomaly, producing hydrothermal circulation in the shallow crust that emerges as thermal springs at the surface (Allis et al. 1979; Koons \& Craw 1991; Koons et al. 1998; Reyes et al. 2010). 


\section{Copland hot spring}

Copland hot spring (43.629S, 169.946E, $440 \mathrm{~m}$ asl) is located $12 \mathrm{~km}$ east of the Alpine Fault and $12 \mathrm{~km}$ west of the Main Divide, where Copland valley is deeply incised between $>2000 \mathrm{~m}$ peaks and glaciated ridges of the central Southern Alps (Fig. 1A,B). The spring is of interest as it has the strongest discharge of both water and gas and is the second hottest and the most chemically evolved of about forty thermal springs along the rapidly uplifting part of the central Alpine Fault (Fig. 1A). Copland hot spring is unusual in the region in that it effervesces abundant $\mathrm{CO}_{2}$ and has precipitated a large travertine deposit. The spring is within the Westland National Park, and bathing pools downstream from the main upwelling vent are a popular destination for hikers.

The spring emanates through a thin cover of debris fan deposits and alluvial gravels (Fig. 2), estimated to be $<50 \mathrm{~m}$ thick at the site, overlying fractured garnet-zone schist (Alpine schist) that forms the dominant rock type along the western Southern Alps (Cox \& Barrell 2007).
Strongly effervescent $\mathrm{CO}_{2}$-rich water emerges at approximately $56-58^{\circ} \mathrm{C}$ into a $1.5 \times 1 \times 1 \mathrm{~m}$ vent pool, then discharges at $6 \pm 11 \mathrm{sec}^{-1}$ through a small restricted channel (cross-sectional area $300 \mathrm{~cm}^{2}$ with average flow velocity $0.2 \mathrm{~m} \mathrm{sec}^{-1}$ ) and out across a terrace of travertine. We estimate over $90 \%$ of the fluid emerges through the source pool, but seeps of $\mathrm{CO}_{2}$ gas and hot water emanate from other small vents nearby. The temperature of the ground approximately $0.7 \mathrm{~m}$ below surface, mostly within travertine or underlying debris-flow deposits or alluvium, was mapped using a calibrated thermistor $\left( \pm 0.1^{\circ} \mathrm{C}\right)$. There is a strong thermal anomaly in the ground with an area $>50 \mathrm{~m}^{2}$ associated with the upwelling vent pool, and a secondary, less intense anomaly near the bathing pools associated with downwards seepage of hot water into the travertine terrace (Fig. 3). Continuous monitoring of fluid discharge at Copland spring has yet to be attempted, but is complicated by the two-phase flow, our inability to constrain flow at subsidiary vents, heat of the fluid and the limited site engineering that is permitted due to site conservation values.

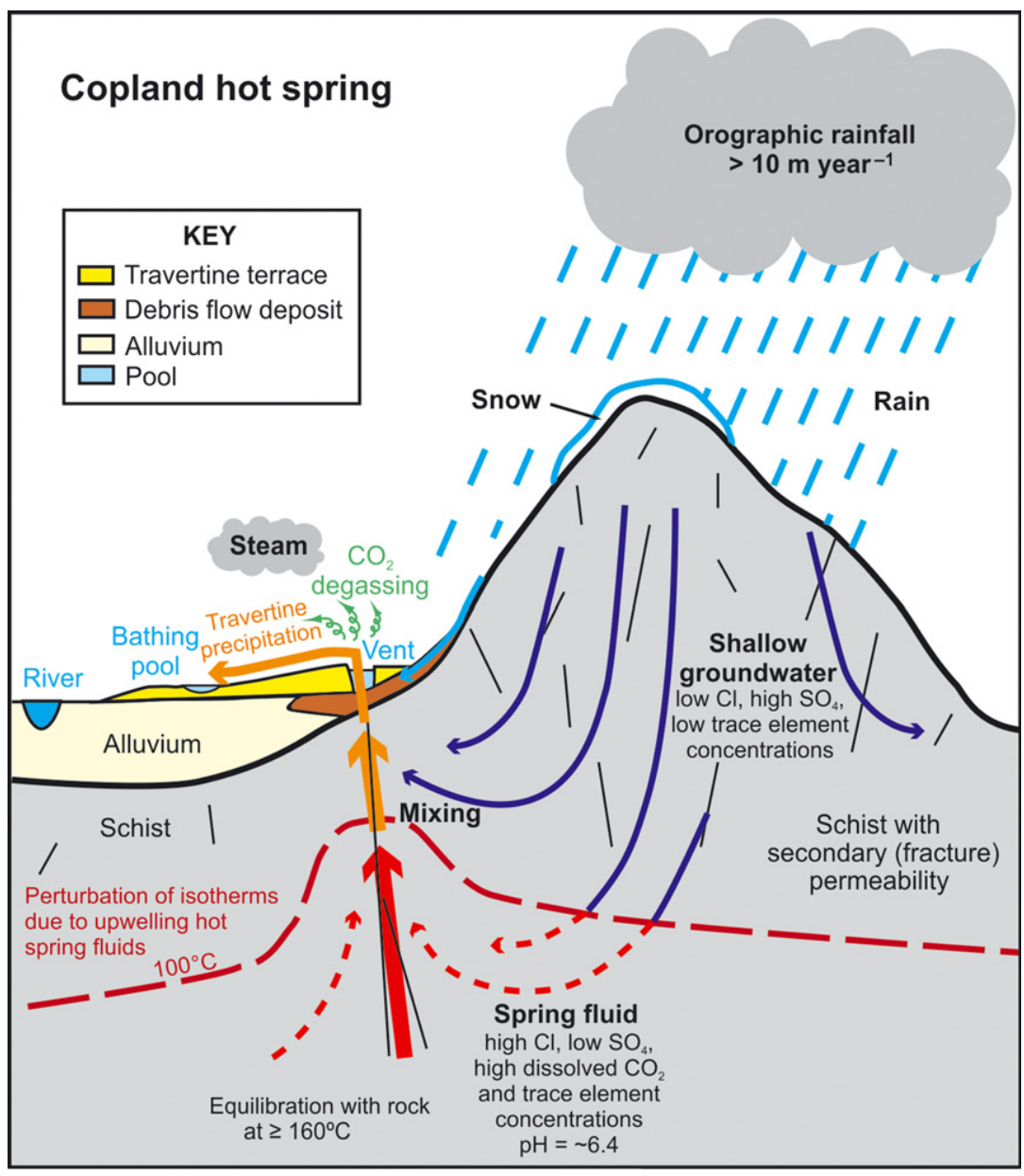

Fig. 2. Cartoon of the hydrothermal circulation that results in Copland hot spring. Rapid uplift and strong erosion of the Southern Alps in the hanging wall of the Alpine Fault has perturbed the thermal structure of the upper crust, leading to geothermal activity and a number of thermal springs. Elevated topography locally drives circulation and cooling from the surface, whereas rapid uplift and conduction drive buoyancy driven circulation from depth. Horizontal and vertical dimensions are not drawn to scale. 


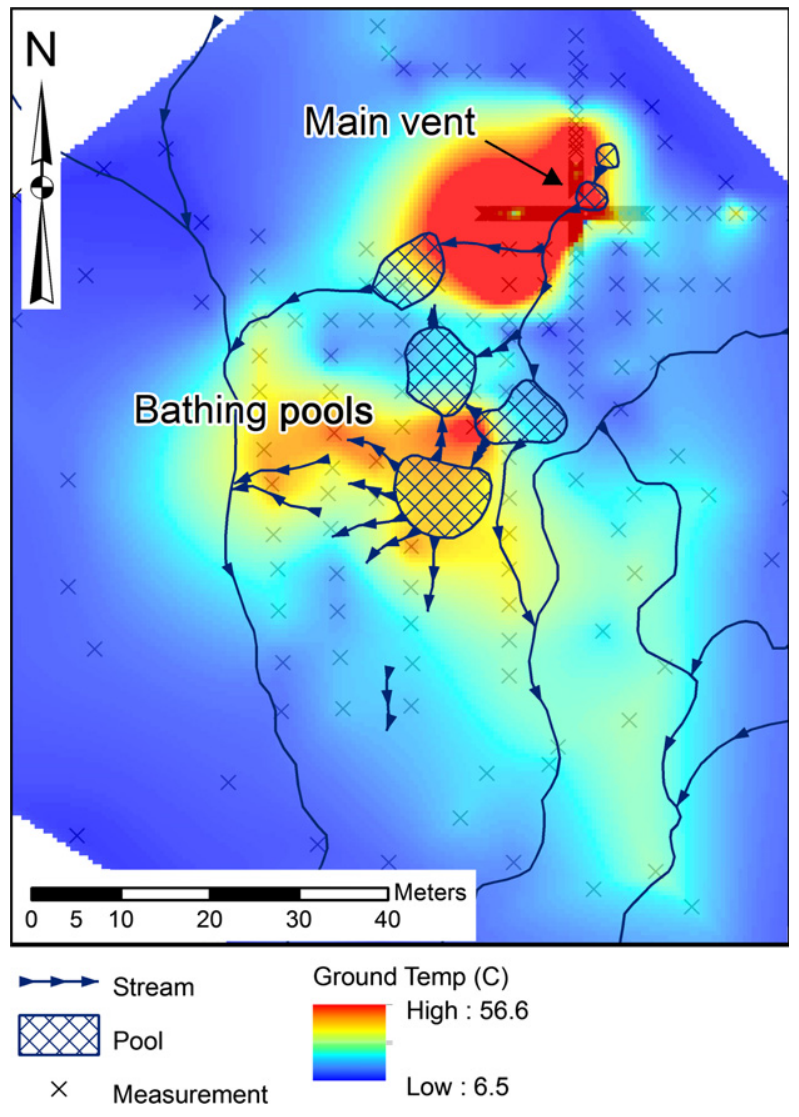

Fig. 3. Thermal map of ground temperature at depths of approximately $0.7 \mathrm{~m}$, as measured on 2 September 2009. X symbols show the location of 298 datapoints, collected by hammering a steel rod into the ground, quickly removing it and inserting a fibre glass probe with a thermistor on its tip, then reading the temperature once the probe had thermally equilibrated. The principal anomaly is adjacent to the main upwelling vent pool, where temperatures reach $56.6^{\circ} \mathrm{C}$. Hot water flows out from the vent across the ground, into bathing pools, where we interpret a secondary thermal anomaly from seepage down into the travertine. Over $8000 \mathrm{~m}^{2}$ is anomalous above $10^{\circ} \mathrm{C}$ mean annual air temperature, but much of which seems to reflect surface flow or shallow subsurface flow immediately beneath the travertine.

\section{Hydrogeology}

There is a paucity of information available on the in situ permeability of rocks in the Southern Alps, and none of it formally published. Although work has been completed recently in the Alpine Fault and its damage zone (Sutherland et al. 2012), to our knowledge, only one investigation has quantified hydraulic properties of fractured Alpine schist in the hanging wall further from the fault. Hydraulic testing was recently completed for a hydroelectric power project near Amethyst Stream, Wanganui River, $1.5 \mathrm{~km}$ from the Alpine Fault (see Table S1, Fig. 1A) where garnet-zone schists contain spaced fractures and shears and are likely to be directly comparable with Alpine schist at Copland valley. These rocks were regionally metamorphosed to either greenschist or amphibolite facies during the Jurassic-Cretaceous and uplifted during the Neogene (Little et al. 2005). They form part of the Haast Schist Group, which is also exposed in the Otago region (Fig. 1A), but where quartzofeldspathic-dominated schist was regionally metamorphosed in the Jurassic and uplifted in Early Cretaceous (Mortimer 1993).

On the basis of regional observations in both Otago and the Southern Alps (Table S1), Alpine schist forming the mountains around Copland valley is expected to have $>10 \mathrm{~m}$ scale (intrinsic) fracture permeability of between $10^{-15}$ and $10^{-12} \mathrm{~m}^{2}$. Corresponding groundwater hydraulic conductivities are estimated to be approximately $10^{-8}$ to $10^{-5} \mathrm{~m} \mathrm{sec}^{-1}$, assuming saturated conditions and standard values of viscosity and specific gravity (based on water at $10^{\circ} \mathrm{C}$ and $\left.1 \mathrm{~atm}\right)$. An effective fracture porosity of between $10^{-3}$ and $10^{-1}$ (i.e. $0.1-10 \%$ ) would cover the range expected from fracture densities encountered in Amethyst drill cores and textbook values (e.g. Freeze \& Cherry 1979; Domenco \& Swartz 1990; Supporting Information). Fractured Alpine schist permeability is therefore similar to damage-zone mylonite (approximately $10^{-14} \mathrm{~m}^{2}$ ), but higher than cataclasite (approximately $10^{-16}$ to $10^{-17} \mathrm{~m}^{2}$ ) and the principal slip zone (approximately $10^{-19} \mathrm{~m}^{2}$ ) of the Alpine Fault (Sutherland et al. 2012).

\section{Recent earthquakes}

Three major earthquakes occurred in the southern South Island during 2009-2013 (Fig. 1A). A moment magnitude (Mw) 7.8 earthquake occurred in Dusky Sound Fiordland at 21:22 (NZST) on 15 July 2009, centred $350 \mathrm{~km}$ southwest of the Copland hot spring. Low-angle thrusting on the Australian-Pacific plate interface produced shaking intensities not felt in South Island for at least 80 years (Fry et al. 2010). Reverse slip of 5-6 $\mathrm{m}$ at the hypocentre produced shifts at cGPS monitoring stations, with over $300 \mathrm{~mm}$ of coseismic horizontal motion and approximately $50 \mathrm{~mm}$ of post-seismic motion at the station nearest the hypocentre, and discernable coseismic offsets throughout the lower South Island (Beavan et al. 2010a,b; see below). The Mw7.8 Dusky Sound earthquake was notable for the relatively small amount of high-frequency $(>5 \mathrm{~Hz})$ shaking given the size of the event (Fry et al. 2010).

On 4 September 2010 at 04:36 (NZST), a Mw7.1 earthquake occurred near Darfield, Canterbury, centred $180 \mathrm{~km}$ east of the Copland hot spring. The event ruptured the 30-km-long Greendale Fault (Quigley et al. 2010), previously concealed beneath the Canterbury alluvial outwash plains, within a network of faults that accommodates distributed deformation east of the Alpine Fault (Cox et al. 2012a; Litchfield et al. 2013). Right-lateral strike-slip displacement reached $5.3 \mathrm{~m}$ at the surface, averaging $2.5 \pm 0.1 \mathrm{~m}$ (Quigley et al. 2012), initiating a prolonged 
aftershock sequence that lasted throughout 2011 and 2012. The largest and most damaging aftershock was the Mw6.3 Christchurch earthquake at 12:51 (NZST) on 22 February 2011, which occurred on an oblique thrust fault beside the volcanic rocks of Banks Peninsula (Beavan et al. 2011; Kaiser et al. 2012) at a distance of $220 \mathrm{~km}$ from Copland hot spring.

The Canterbury earthquakes radiated anomalously high levels of seismic energy relative to their magnitudes. The Mw7.1 Darfield earthquake had an energy magnitude (Me) of 7.4, with peak vertical ground accelerations reaching $1.3 \mathrm{~g}$ near the epicentre, whereas the Mw6.3 Christchurch aftershock had an Me of 6.7 and produced vertical accelerations of up to $2.2 \mathrm{~g}$ (Cousins \& McVerry 2010; Gledhill et al. 2011; Reyners 2011). Attenuation with distance was stronger for the Mw6.3 than in the Mw7.1, as expected for the approximately one magnitude step difference between the two events, with correspondingly greater attenuation of accelerations than shaking velocities or displacements (Kaiser et al. 2012). However, the close proximity of the Mw6.3 earthquake to the city of Christchurch, the shallow source and exceptionally strong vertical ground motions resulted in high levels of damage and human casualties (e.g. Bradley \& Cubrinovski 2011; Fry et al. 2010; Orense et al. 2011). In stark contrast, the Mw7.8 Dusky Sound earthquake of 2009 occurred in a sparsely populated region in the remote area of Fiordland, radiated a similar amount of seismic energy (Me7.3) in a predominantly offshore (south-westward) direction and produced relatively little damage and no casualties (Reyners 2009). Hydrological responses to these South Island earthquakes were observed in monitoring wells at near-, intermediateand far-field distances (Cox et al. 2010, 2012b; Gulley et al. 2013).

The seismicity rate in the central Southern Alps increased significantly after the Mw7.8 Dusky Sound and Mw7.1 Darfield earthquakes, but not after the energetic Mw6.3 Christchurch aftershock (Boese et al. 2014). Delayed-triggered swarms of low-magnitude earthquakes occurred beneath the Main Divide 20-25 km north-east of Copland valley, but were not detected in the immediate vicinity of the Copland hot spring. The largest numbers of events occur in swarms delayed several hours to tens of hours after arrival of the remotely sourced seismic waves. Seismicity triggered by the Mw7.8 Dusky Sound earthquake continued for approximately 5 days in the central Southern Alps and at least 2 days after the Mw7.1 Darfield earthquake.

\section{COPLAND HOT SPRING TEMPERATURE OBSERVATIONS}

Rainfall, air and pool temperatures at Copland hot spring were continually monitored between March 2009 and July
2011 using a Hobo U12 temperature logger (relative precision $\pm 0.04^{\circ} \mathrm{C}$, accuracy $\pm 0.4^{\circ} \mathrm{C}$ ) recording at 15 min intervals, and a Hobo RG3-M tipping bucket rain gauge $\left(0.2 \mathrm{~mm}\right.$ per tip; air temperature precision $\pm 0.1^{\circ} \mathrm{C}$, accuracy $\pm 0.5^{\circ} \mathrm{C}$ ) situated $80 \mathrm{~m}$ south of the spring. The U12 logger was submerged at a depth of $1 \mathrm{~m}$ in the vent pool formed where fluid emanates at the surface. This pool is quite distinct from pools where the downstream flow is dammed for bathing.

Water temperatures fluctuated about background values of $57-58^{\circ} \mathrm{C}$, with up to $\pm 0.1^{\circ} \mathrm{C}$ diurnal variation, but fell dramatically during episodes of heavy rainfall. Abrupt temperature drops occurred as soon as it started raining with more gradual recovery to background values $3-5 \mathrm{~h}$ after the rain stopped (Fig. 4). Spring water cooled to as low as $36.6^{\circ} \mathrm{C}$ when $535 \mathrm{~mm}$ of rain fell in a single storm between 25 and 28 April 2009. There is little surface runoff directly into the vent pool, so cooling is primarily a result of subsurface flow, as reflected by the quick recovery.

A distinct and very different cooling occurred following the Mw7.8 Dusky Sound earthquake on 15 July 2009. After a delay of $180 \pm 15 \mathrm{~min}$, there was first a slight $0.20 \pm 0.05^{\circ} \mathrm{C}$ rise in spring temperature to $58^{\circ} \mathrm{C}$, followed by a slow $0.90 \pm 0.05^{\circ} \mathrm{C}$ cooling over a 5 -day period to a new lower background value approximately $57^{\circ} \mathrm{C}$ (Fig. 5A). Fifteen months later on 4 September 2010, the Mw7.1 Darfield earthquake centred $180 \mathrm{~km}$ east of the spring produced a very similar response. After a delay of $140 \pm 15 \mathrm{~min}$, there was a $1.1 \pm 0.2^{\circ} \mathrm{C}$ cooling (Fig. $5 \mathrm{~B}$ ) that accentuated the long-term temperature depression, but was then overprinted by rainfall-related cooling between 5 and 7 September.

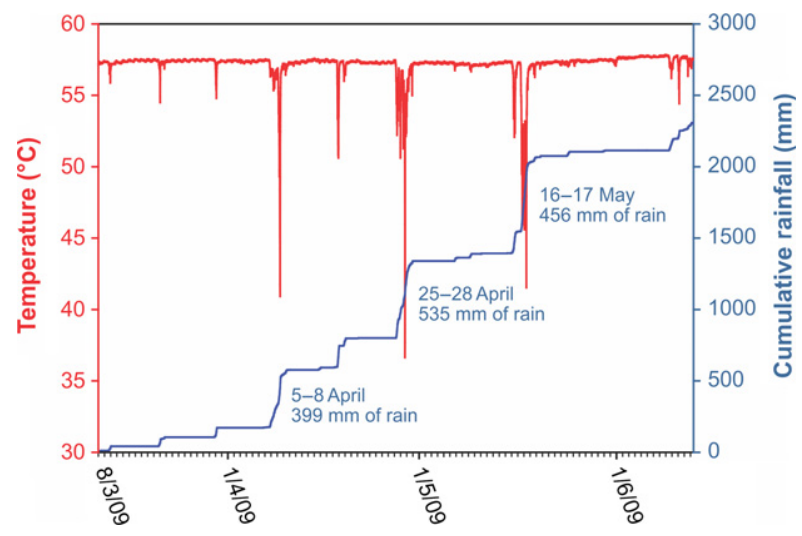

Fig. 4. Graph of cumulative rainfall ( $\mathrm{mm}$, blue line) and pool water temperature $\left({ }^{\circ} \mathrm{C}\right.$, red) during the period 8 March-13 June 2009. A strong correlation exists between the main rainfall events, marked by large steps, and major water temperature depression. A subtle diurnal $\pm 0.1^{\circ} \mathrm{C}$ fluctuation occurs when temperatures returned to background values of $57-58^{\circ} \mathrm{C}$ between the rainfall events. 

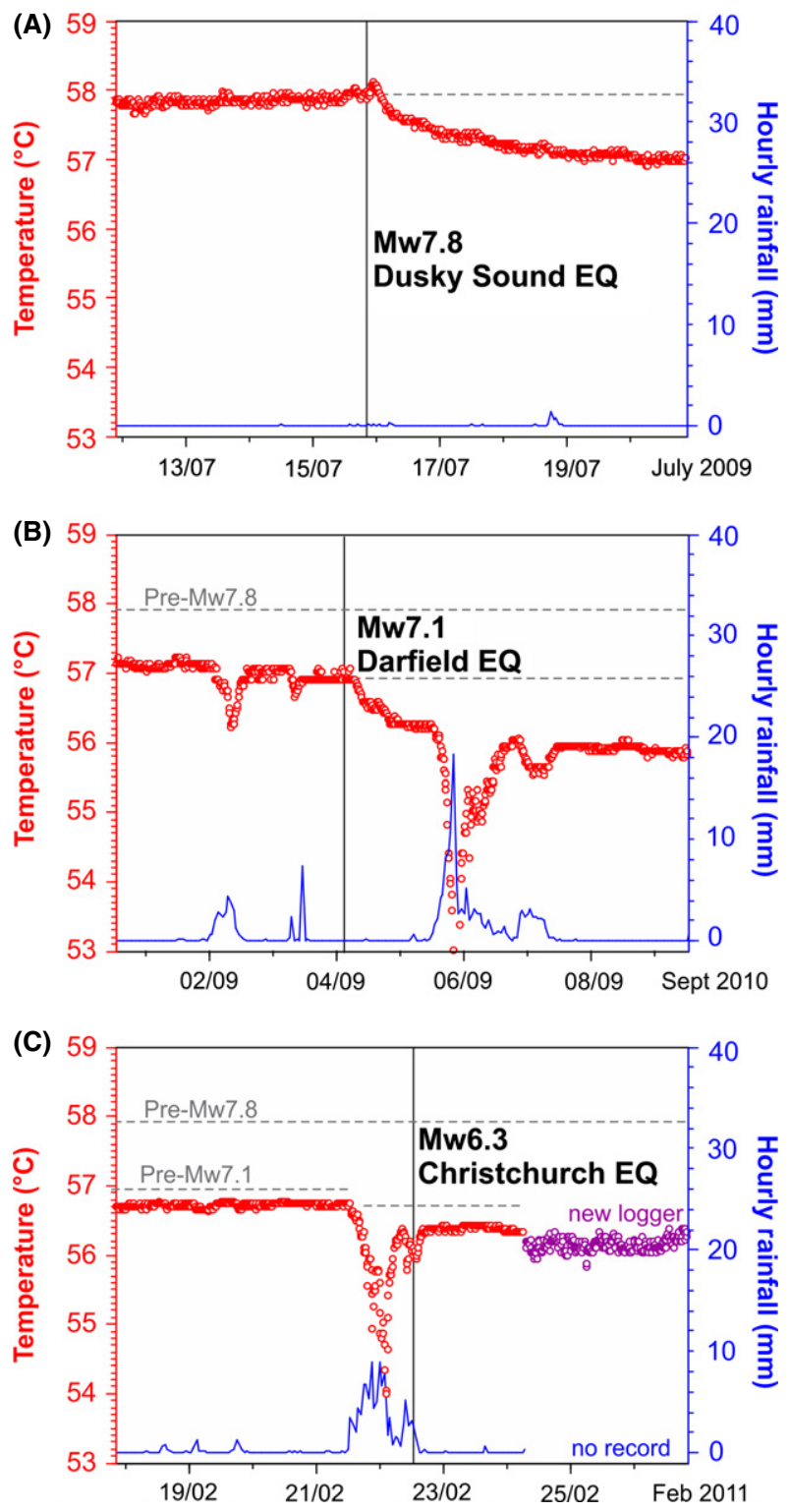

Fig. 5. Graphs of Copland spring temperatures (red) and hourly rainfall (blue) at the time of recent earthquakes: (A) Mw7.8 Dusky Sound (15 July 2009), (B) Mw7.1 Darfield (4 September 2010) and (C) Mw6.3 Christchurch (22 February 2011). The temperature logger is submerged $1 \mathrm{~m}$ below the pool surface and is not directly affected by surface waters. A new U12 logger was deployed in late February 2011 (purple symbols), when equipment problems also resulted in missing rainfall data.

The background pool temperature remained depressed at approximately $56^{\circ} \mathrm{C}$ from September 2010 until February 2011 when the Mw6.3 Christchurch aftershock occurred $220 \mathrm{~km}$ to the east. The pool temperature was already lower at the time of the earthquake due to a rainstorm that had started the previous day. Consequently, any shaking-induced signal is masked by the cooling caused by $104 \mathrm{~mm}$ of rain (Fig. 5C). The pool had been at a background temperature at $56.74^{\circ} \mathrm{C}$ on 21 February prior to the rain, but post-rainfall recovery was to a new background at $56.38^{\circ} \mathrm{C}$ by $16: 45$ on 22 February, only $4 \mathrm{~h}$ after the earthquake and $2 \mathrm{~h}$ after it stopped raining. The earthquake may have induced a small $0.36 \pm 0.05^{\circ} \mathrm{C}$ temperature depression, accomplished over a period $<4 \mathrm{~h}$, but masked by the effects of rainfall. If real, this was comparatively short and steplike compared with the cooling induced by the Mw7.8 Dusky Sound and Mw7.1 Darfield earthquakes. Due to concerns over battery life, a new temperature logger was deployed on 24 February 2010 that performed with lower precision and measured slightly cooler temperatures that reflect instrument performance/ calibration issues (Fig. 5C - see annotation). Consequently, when combined with rainfall masking, we are not confident that there was any lasting temperature departure caused by the Mw6.3 Christchurch earthquake, but certainly the response was different if any occurred at all. By 24 March 2011, the spring temperature had recovered to background temperatures of approximately $57^{\circ} \mathrm{C}$, equivalent to those prior to the Mw7.1 Darfield earthquake. In October 2013, the background spring temperature was still at approximately $57.1^{\circ} \mathrm{C}$, yet to recover to the state it was prior to the Mw7.8 Dusky Sound earthquake in July 2009.

Earthquake-related cooling responses have been timeshifted with regard to earthquake origin time, so they can be compared (Fig. 6). These responses are quite distinct from the sharp drops and recoveries resulting from rainfall (Fig. 4). The Mw7.1 Darfield earthquake cooling in September 2010 started from approximately $1^{\circ} \mathrm{C}$ lower background temperature (at approximately $57^{\circ} \mathrm{C}$ ), but followed a trajectory very similar to the cooling caused by the Mw7.8 Dusky Sound earthquake in July 2009. The main differences were as follows: (i) the Mw7.8 Dusky Sound earthquake showed a slight temperature increase before cooling, which was not observed following the Mw7.1 Darfield earthquake; (ii) the response to the Mw7.1 Darfield earthquake was overprinted with rainfall-related cooling to as low as $45.6^{\circ} \mathrm{C}$. We consider these to represent minor departures from what was otherwise a characteristic temperature response that predominantly reflects cooling caused by earthquake-induced changes in the flow regime, with temperature decay that is related to thermal capacitance of the hydrothermal system (see Discussion).

\section{FLUID CHEMISTRY OF COPLAND HOT SPRING}

Copland hot spring waters have the highest concentration of dissolved solids of thermal springs along the central Alpine Fault and the second highest temperature (Reyes et al. 2010; Menzies 2012). The waters are slightly acidic $(\mathrm{pH}=6.1-6.6)$, have high alkalinity (approximately $17000 \mu \mathrm{eq} 1^{-1}$ ) and degas $\mathrm{CO}_{2}$ as they upwell. They have elevated concentrations of $\mathrm{Li}, \mathrm{B}, \mathrm{Na}, \mathrm{Mg}, \mathrm{Si}, \mathrm{Cl}, \mathrm{K}, \mathrm{Mn}$, 


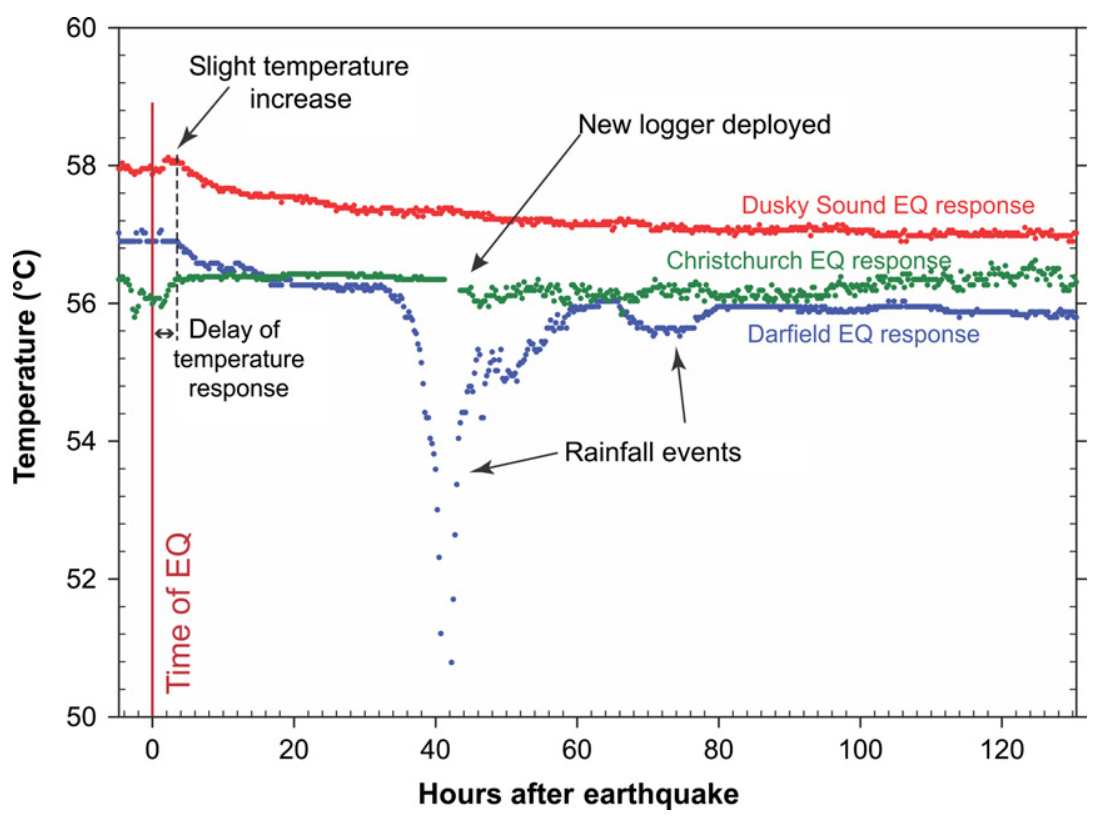

Fig. 6. Copland spring temperatures, time-shifted relative to the source time of each earthquake, so the nature of earthquake-related responses can be more closely compared.
$\mathrm{Rb}, \mathrm{Sr}, \mathrm{Ca}$ and $\mathrm{Ba}$, and low concentrations of $\mathrm{SO}_{4}$ (Table 1) relative to other springs in the central Southern Alps. Stable oxygen and hydrogen isotopic signatures plot on or near the global meteoric water line (Barnes et al. 1978; Reyes et al. 2010; Menzies 2012), indicating fluids are principally derived from deep infiltration of precipitation (rainfall or snow melt) into the schist mountains. Application of the silica (no steam loss) geothermometer of Truesdell (1976) to fluid chemical analyses returned equilibration temperatures of $153-164^{\circ} \mathrm{C}$ (Table 1). This suggests circulation to depths of $2-3 \mathrm{~km}$ if the local geothermal gradient is similar to the $62.6^{\circ} \mathrm{C} \mathrm{km}^{-1}$ gradient measured at the Alpine Fault (Sutherland et al. 2012), although thermal modelling suggests that geothermal gradients should be higher in the hanging wall away from the Alpine Fault due to the cooling influence of relatively static footwall rocks (Koons 1987). Clearly, the deep fluids have cooled during upwelling, but low sulphate concentrations indicate that this is principally by conduction rather than dilution by cool shallow meteoric fluids. Conductive cooling may result in silica precipitation that would result in an underestimation of the maximum equilibration temperature using the silica geothermometer. Unfortunately, major cation concentrations $(\mathrm{Na}, \mathrm{K}, \mathrm{Mg}, \mathrm{Ca})$ indicate that the Copland hot spring fluids are immature waters far from equilibrium with the host rock Alpine schists (following Giggenbach 1988) precluding the use of a range of geothermometers (e.g. Giggenbach et al. 1993; Menzies 2012). However, this lack of equilibration probably excludes deep fluid-rock interaction at temperatures much $>200^{\circ} \mathrm{C}$ (see also Reyes et al. 2010).

Having observed cooling of Copland hot spring in response to rainfall and the Mw7.8 Dusky Sound (July
2009) earthquake, a series of temperature, conductivity and $\mathrm{pH}$ readings were taken at the vent pool throughout 2010 and 2011. The spring fluids showed a subtle shift to lower conductivity and higher $\mathrm{pH}$ after the Mw7.1 Darfield earthquake (Fig. 7), changing from a mean ( \pm standard error) conductivity of $2311 \pm 56$ to $2074 \pm 27 \mu \mathrm{S} \mathrm{cm}^{-1}$ and $\mathrm{pH}$ $6.43 \pm 0.01$ to $6.53 \pm 0.02$. Together with the records of cooling, these chemical observations are interpreted to reflect a change in the dilution of deep upwelling thermal waters (more acidic, more conductive) by near-surface (more basic, less conductive) groundwater.

Samples of Copland spring fluid (Table 1) were collected for geochemical analysis on 8 March 2009, 3 October 2010, 8 November 2010 and 23 February 2011, spanning the period of the recent earthquakes, and can be compared with published analyses of fluids collected about 1975 and 27 November 2005 (Barnes et al. 1978; Reyes et al. 2010 respectively). Concentrations of some cations and anions have changed systematically over time (Fig. 8, Table 1). Cl concentrations were highest $\left(164,167\right.$ and $\left.154 \mu \mathrm{g} \mathrm{g}^{-1}\right)$ in samples collected before the recent earthquakes, compared with $147 \mu \mathrm{g} \mathrm{g}^{-1}$ in a sample from 2 months after the Mw7.1 Darfield earthquake and $137 \mu \mathrm{g} \mathrm{g}^{-1}$ in a sample collected 1 day after the Mw6.3 Christchurch earthquake. Concentrations of $\mathrm{Li}, \mathrm{B}, \mathrm{Na}, \mathrm{K}, \mathrm{Sr}$ and $\mathrm{Ba}$ were also higher in samples collected before the earthquakes, than those during and after the earthquakes. $\mathrm{SO}_{4}$ concentrations are variable and lower in 1978 and 2005 analyses (Barnes et al. 1978; Reyes et al. 2010) than those of this study. Such systematic differences between samples corroborate the notion of earthquake-induced changes in fluid chemistry observed in $\mathrm{pH}$ and conductivity over time. Other elements (F, Si, Mg, Ca, Rb, Fe, Mn, Br and $\mathrm{Cs}$ ) show no 


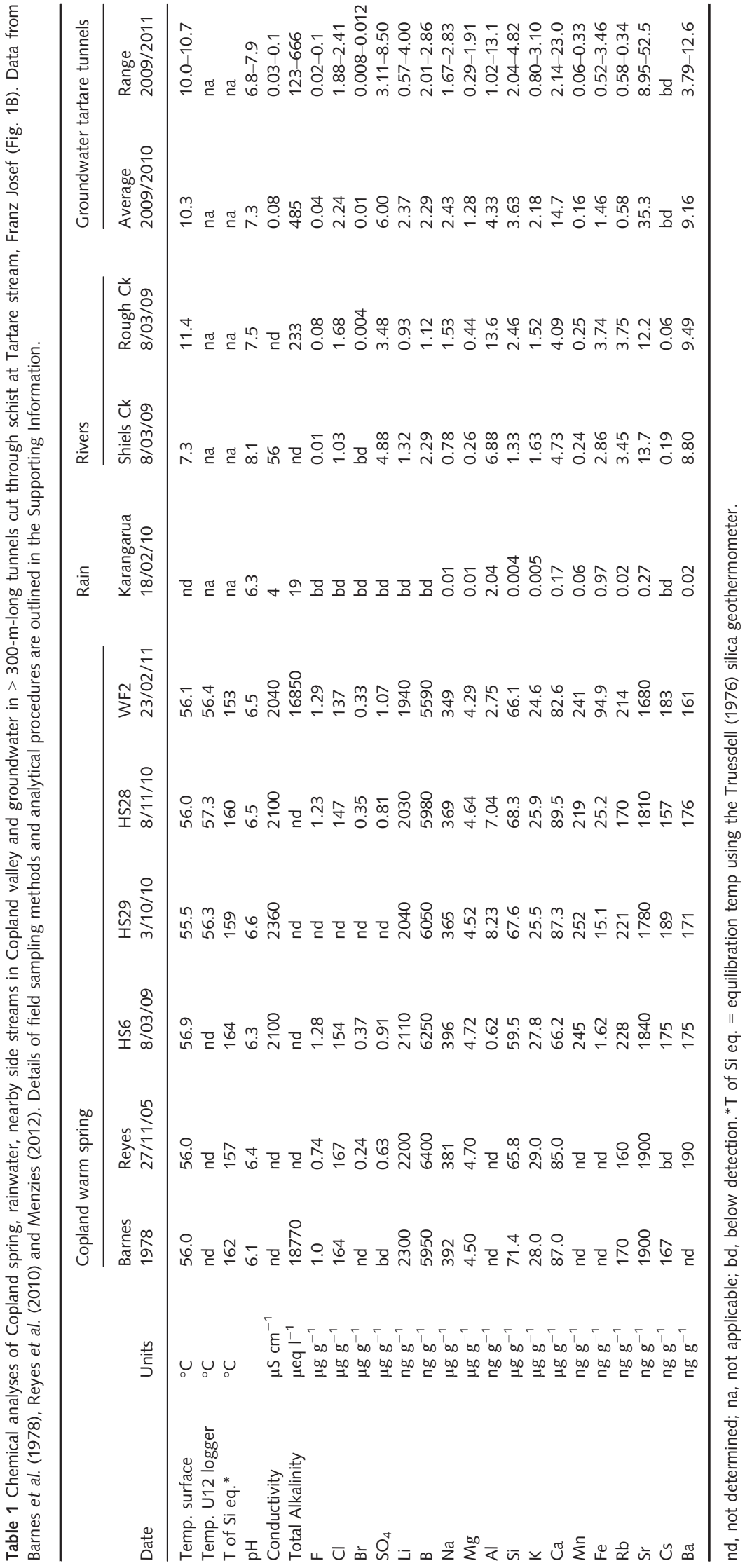




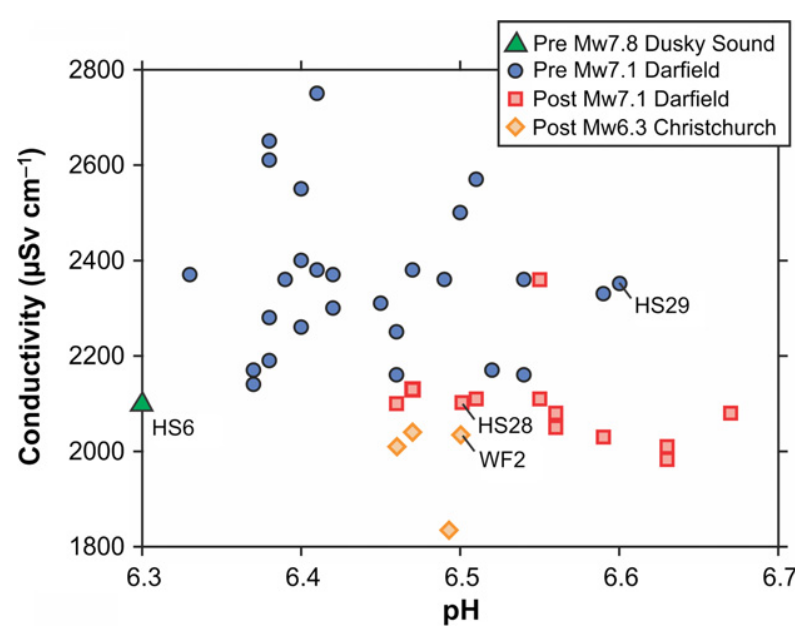

Fig. 7. Graph of specific conductivity versus $\mathrm{pH}$ at Copland hot spring, showing earthquake-induced changes. Measurements are classified according to time relative to earthquakes, showing a clear lowering of specific conductivity (i.e. total dissolved solids) and $\mathrm{pH}$ increase from pre- (blue circles; 31 December 2009-22 August 2010) to post- (red squares; September-October 2010) Mw7.1 Darfield earthquake.

regular changes with time and earthquake events. This may be because the temporal variability in concentration of these elements (e.g. due to seasonal variation, subsurface precipitation of calcite or rainfall) is higher than any earthquake-induced changes or because any changes were insufficient to exceed analytical uncertainties for these elements.

Concentrations of most elements except $\mathrm{SO}_{4}$ are considerably lower in surface waters such as rain, river waters and shallow groundwater in schist (Table 1), commensurate with conductivities that are two orders of magnitude lower than spring fluid. Surface waters are more oxygenated so carry sulphur as $\mathrm{SO}_{4}$, whereas deeper hydrothermal fluids tend to be sulphide-bearing (Barnes et al. 1978). Mixing of surficial water and shallow groundwater into deep hydrothermal fluid should therefore decrease the concentration of anions and cations, as well as temperature, increasing only $\mathrm{SO}_{4}$ and $\mathrm{pH}$. Assuming the concentration of $\mathrm{SO}_{4}$ is near-zero in the deep hydrothermal fluid, and shallow fluid has a $6.0 \mu \mathrm{g} \mathrm{g}^{-1} \mathrm{SO}_{4}$ equivalent to the average groundwater in Tartare Tunnels (Table 1), mass balance between the pre-earthquake sample HS6 $\left(\mathrm{SO}_{4}=0.91 \mu \mathrm{g} \mathrm{g}^{-1}\right)$ and average Tartare groundwater suggests about $15 \%$ of Copland hot spring prior to the earthquakes was derived from shallow fluid. Assuming the spring did not experience major flow rate changes as a result of seismic events, corroborated by the lack of any significant change reported by Department of Conservation staff and visitors present at the time, mass balance between post-earthquake sample WF2 $\left(\mathrm{SO}_{4}=1.07 \mu \mathrm{g} \mathrm{g}^{-1}\right)$ and Tartare Tunnel groundwater using $\mathrm{SO}_{4}$ as a tracer suggests the earthquake increased the proportion of shallow end member fluid to $18 \%$. Alternate mixing models are also feasible, but yield mixing ratios around 5:1 and similarly small changes in response to earthquakes. In the absence of information on absolute changes in discharge, none are able to distinguish whether there was an increase in volume of shallow fluid mixing into the hot spring fluid or decrease in deep hydrothermal fluid.

\section{DYNAMIC SHAKING}

National seismometers closest to, and surrounding, Copland hot spring are FOZ (22.2 km north-west), MCNS (16.6 km southeast), FGPS (19.4 km north-east) and LPLS (43.3 km south-west) (GeoNet 2014; see also Supporting Information). Peak ground accelerations (PGA) and peak velocities $(\mathrm{PGV})$ are listed in Table 2, reported also in the text as absolute acceleration $(\% \mathrm{~g})$ values. Shaking from the Mw7.1 Darfield earthquake (PGA $=0.5$ $2.8 \% \mathrm{~g}$ ) was more intense than the Mw7.8 Dusky Sound event (PGA $=0.4-2.3 \% \mathrm{~g})$, which in turn was more intense than the Mw6.3 Christchurch aftershock $(\mathrm{PGA}=0.1-0.5 \% \mathrm{~g})$. Peak ground accelerations mostly occurred at periods of $0.4-1.0 \mathrm{sec}$. Simplified interpolation between seismometers, using the nearest-neighbours function (Sibson 1981) in ArcGIS, suggests peak ground accelerations in the vicinity of the Copland hot spring are very unlikely to have exceeded approximately $2 \% \mathrm{~g}$ during these earthquakes, corresponding to New Zealand Modified Mercalli (MM) intensities (Dowrick 1996) of III-IV (weak to light). The seismic energy densities at Copland hot spring, estimated from the empirical relation of Wang \& Manga (2010b), are from $10^{-2}$ to $10^{-1} \mathrm{~J} \mathrm{~m}^{-3}(\mathrm{Mw} 7.8=$ $0.24 \mathrm{~J} \mathrm{~m}^{-3}$, Mw7.1 $=0.18 \mathrm{~J} \mathrm{~m}^{-3}$, Mw6.3 $=0.01 \mathrm{~J} \mathrm{~m}^{-3}$; Table 2). The static stress changes at Copland hot spring (Table 2) are estimated to have been approximately $0.48 \mathrm{kPa}$ for both the Mw7.8 and Mw7.1 earthquakes, but only $0.03 \mathrm{kPa}$ for the Mw6.3, based on estimations from the published seismic moment (Mo) values of $2.72 \times 10^{20} \mathrm{~N} \mathrm{~m}$ (Fry et al. 2010), $3.46 \times 10^{19} \mathrm{~N} \mathrm{~m}$ (Gledhill et al. 2011) and $3.72 \times 10^{18} \mathrm{~N} \mathrm{~m}$ (Kaiser et al. 2012), using the equation Stress $=\mathrm{Mo} /\left(4 \pi \mathrm{D}^{3}\right)$ where $\mathrm{D}$ is the epicentral distance (Brodsky et al. 2003).

Absolute acceleration response spectra differ markedly between the Mw7.8 Dusky Sound and the Mw7.1 Darfield earthquakes (Fig. 9A,B). There was high power at 1- to 2.5-sec periods during the Mw7.1, which appears to have been a characteristic of spectra recorded elsewhere in South Island (Cousins \& McVerry 2010), and many seismometers recorded relatively small amounts of low period $(<0.2 \mathrm{sec})$ shaking during the Mw7.8 (Fry et al. 2010) including FOZ, FGPS and MCNS. Peak ground accelerations were higher during the Mw7.1 Darfield earthquake (see also Table 2), particularly well exemplified by the FOZ N horizontal (north-south) channel (Fig. 9C). However, none of the accelerations were particularly strong in 
Fig. 8. Evolution of Copland hot spring fluid chemistry. Concentration of trace elements in Copland spring waters plotted against chloride concentration for samples taken before the Mw7.8 Dusky Sound earthquake (blue circles), after Mw7.1 Darfield earthquake (red square and red dashed line) and after Mw6.3 Christchurch earthquake (orange diamond). PreMw7.8 Dusky Sound earthquake data taken from (Barnes et al. 1978; Reyes et al. 2010) and HS6 in March 2009 - see Table 1.
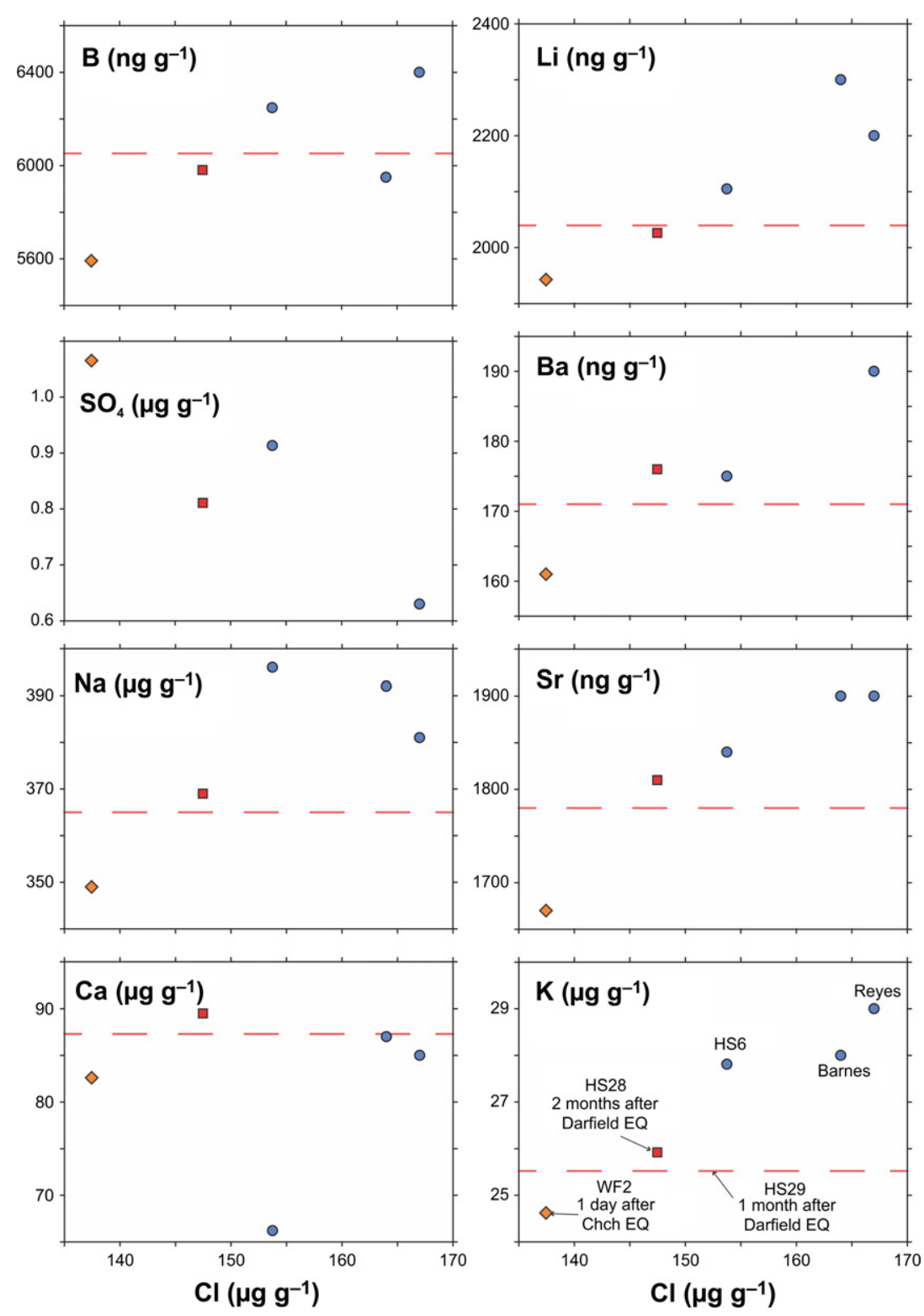

the seismometers surrounding Copland hot spring, which is not surprising given the epicentral distances involved. In these recent earthquakes, FOZ recorded lower spectral accelerations than MCNS, FGPS and LPLS, which we interpret to be largely a site response effect (Fig. 9A,B). FOZ is situated on a solid bedrock site (subsoil category Type B - Rock, as defined in NZS1170.5 by Standards New Zealand 2004), whereas the other seismometers are situated on thick sequences of compact glacial gravels (Type D - deep or soft soils). It is therefore likely that of any of the GeoNet seismometers, the national network station FOZ, situated $15 \mathrm{~km}$ from Copland hot spring, best represents the shaking of bedrock and mountains surrounding Copland valley, through which the thermal spring-waters flow (see also Supporting Information).
The 2007-2012 record of shaking at FOZ, plotted as the maximum PGA measured from earthquakes $>$ Mw4 (Fig. 9D), shows that the Mw7.8 Dusky Sound, Mw7.1 Darfield and Mw6.3 Christchurch earthquakes produced the highest levels of shaking observed over the period when the spring temperatures were being monitored (March 2009-July 2011). However, only the Mw7.8 and Mw7.1 earthquakes were able to produce a clear response in Copland hot spring that followed characteristic cooling and did so despite very clear differences in source location, directivity, energy magnitude and spectral behaviour. The ground motion of the Mw7.8 Dusky Sound and Mw7.1 Darfield earthquakes exceeded PGA values of $45 \mathrm{~mm} \mathrm{sec}^{-2}$ and PGV values of $10 \mathrm{~mm} \mathrm{sec}^{-1}$ in both horizontal and vertical directions for nearly all seismographs surrounding 
Table 2 Records of PGA and PGV (hor = horizontal, vert = vertical) for seismometers FOZ, MCNS, FGPS and LPLS during the Mw7.8 Dusky Sound, Mw7.1 Darfield and Mw6.3 Christchurch earthquake. The column COP_SPR contains a simplistic nearest-neighbours interpolation (italics) that accounts for distance to the surrounding seismometers, but not site conditions nor any differences in station instrument types.

\begin{tabular}{|c|c|c|c|c|c|c|}
\hline CODE & UNIT & $\mathrm{FOZ}$ & MCNS & FGPS & LPLS & COP_SPR \\
\hline Instrument & & Episensor & Etna & Etna & Etna & Interpolation \\
\hline Site latitude S & Degrees & -43.5338 & -43.7381 & -43.4649 & -43.7163 & -43.6295 \\
\hline Site longitude E & Degrees & 169.8154 & 170.0971 & 170.0197 & 169.4230 & 169.9464 \\
\hline Site elevation & $\mathrm{m}$ & 54 & 701 & 181 & 23 & 440 \\
\hline Distance to Copland & $\mathrm{km}$ & 22.2 & 16.6 & 19.4 & 43.3 & 0.0 \\
\hline Site geology and strength & ASNZS 1170.5 & B, Rock & D, Deep or soft Soil & D, Deep or soft Soil & D, Deep or soft Soil & B, Rock \\
\hline Site geology and strength & NZS4203 & $\begin{array}{l}\text { A, Rock or very } \\
\text { stiff soil }\end{array}$ & C, Flexible or deep soil & $\begin{array}{l}\text { C, Flexible or deep } \\
\text { soil }\end{array}$ & $\begin{array}{l}\text { C, Flexible or deep } \\
\text { soil }\end{array}$ & $\begin{array}{l}\text { A, Rock or very } \\
\text { stiff soil }\end{array}$ \\
\hline \multicolumn{7}{|c|}{ Mw7.8 Dusky Sound, 15/07/09 09:22:29 } \\
\hline Epicentral distance & $\mathrm{km}$ & 358 & 359 & 375 & 321 & 356 \\
\hline PGA_vert & $\mathrm{mm} \mathrm{sec}{ }^{-1} \mathrm{sec}^{-1}$ & 47.9 & 38.0 & 58.0 & 83.5 & 46.0 \\
\hline PGA_horMAX & $\mathrm{mm} \mathrm{sec}{ }^{-1} \mathrm{sec}^{-1}$ & 52.7 & 100.2 & 118.8 & 229.5 & 91.0 \\
\hline PGV_vert & $\mathrm{mm} \mathrm{sec}-1$ & 11.8 & 8.8 & 10.8 & 15.5 & 10.4 \\
\hline PGV_horMAX & $\mathrm{mm} \mathrm{sec}{ }^{-1}$ & 15.7 & 17.0 & 25.7 & 36.5 & 18.3 \\
\hline Peak dynamic stress* & $\mathrm{MPa}$ & 0.13 & 0.15 & 0.22 & 0.31 & 0.16 \\
\hline Static stress change & $\mathrm{kPa}$ & & & & & 0.48 \\
\hline Energy density ${ }^{\dagger}$ & $\mathrm{J} \mathrm{m}^{-3}$ & & & & & 0.24 \\
\hline \multicolumn{7}{|c|}{ Mw7.1 Darfield, 3/09/10 16:35:41 } \\
\hline Epicentral distance & $\mathrm{km}$ & 191 & 169 & 175 & 223 & 180 \\
\hline PGA_vert & $\mathrm{mm} \mathrm{sec}{ }^{-1} \mathrm{sec}^{-1}$ & 62.1 & 77.6 & 127.9 & 52.4 & 75.1 \\
\hline PGA_horMAX & $\mathrm{mm} \mathrm{sec}{ }^{-1} \mathrm{sec}^{-1}$ & 121.0 & 204.5 & 278.6 & 180.7 & 178.8 \\
\hline PGV_vert & $\mathrm{mm} \mathrm{sec}{ }^{-1}$ & 18.2 & 13.9 & 22.5 & 7.8 & 16.0 \\
\hline PGV_horMAX & $\mathrm{mm} \mathrm{sec}{ }^{-1}$ & 27.3 & 27.4 & 43.5 & 26.6 & 28.8 \\
\hline Peak dynamic stress* & $\mathrm{MPa}$ & 0.23 & 0.23 & 0.37 & 0.23 & 0.25 \\
\hline Static stress change & $\mathrm{kPa}$ & & & & & 0.48 \\
\hline Energy density ${ }^{\dagger}$ & $\mathrm{J}^{-3}$ & & & & & 0.18 \\
\hline \multicolumn{7}{|c|}{ Mw6.3 Christchurch, 21/2/11 23:51:42 } \\
\hline Epicentral distance & $\mathrm{km}$ & 233 & 209 & 217 & 265 & 221 \\
\hline PGA_vert & $\mathrm{mm} \mathrm{sec}{ }^{-1} \mathrm{sec}^{-1}$ & 11.7 & 13.9 & 24.7 & 13.0 & 14.0 \\
\hline PGA_horMAX & $\mathrm{mm} \mathrm{sec}{ }^{-1} \mathrm{sec}^{-1}$ & 17.0 & 47.0 & 48.9 & 32.9 & 35.2 \\
\hline PGV_vert & $\mathrm{mm} \mathrm{sec}-1$ & 2.3 & 2.6 & 2.8 & 1.6 & 2.5 \\
\hline PGV_horMAX & $\mathrm{mm} \mathrm{sec}^{-1}$ & 3.9 & 3.8 & 9.5 & 4.2 & 4.4 \\
\hline Peak dynamic stress* & $\mathrm{MPa}$ & 0.03 & 0.03 & 0.08 & 0.04 & 0.04 \\
\hline Static stress change & $\mathrm{kPa}$ & & & & & 0.03 \\
\hline Energy density ${ }^{\dagger}$ & $\mathrm{J} \mathrm{m}^{-3}$ & & & & & 0.01 \\
\hline
\end{tabular}

* Estimated-PGV max times the shear modulus $\left(3 \times 10^{10} \mathrm{~Pa}\right)$, divided by shear wave velocity $\left(3.5 \mathrm{~km} \mathrm{sec}^{-1}\right){ }^{+} \mathrm{Seismic}$ energy density after Wang \& Manga (2010b).

Copland hot spring, corresponding to dynamic stresses over 0.1 MPa (Table 2). In contrast, during the Mw6.3 Christchurch earthquake, shaking was nearly all measured at $<35 \mathrm{~mm} \mathrm{sec}^{-2}$ and $<5 \mathrm{~mm} \mathrm{sec}^{-1}$ (dynamic stresses $<0.05 \mathrm{MPa}$ ) (Table 2). The maximum static stress changes in the vicinity of Copland hot spring, derived from seismic moment of the earthquakes, were far smaller, being approximately $0.5 \mathrm{kPa}$ for the Mw7.8 Dusky Sound and Mw7.1 Darfield earthquakes and $0.03 \mathrm{kPa}$ for the Mw6.3 Christchurch aftershock. We conclude there is some form of shaking threshold for temperature changes at Copland hot spring, at PGA approximately $0.5 \% \mathrm{~g}$ and dynamic stresses somewhere between 0.05 and $0.1 \mathrm{MPa}$. These are essentially equivalent to thresholds that triggered nearby seismicity beneath the Main Divide 20-25 km north-east of Copland valley (Boese et al. 2014). Over the longer period of 2007-2012, there were five earthquakes that produced PGA at FOZ $>0.2 \%$ g (Fig. 9C) that may have been sufficient to produce a response at Copland hot spring. Records from the FOZ seismometer, as well as the more comprehensive National Seismic Hazard Model (Stirling et al. 2002, 2012), indicate this level of shaking can be expected every 1-10 years (see also Boese et al. 2014).

\section{PERMANENT DEFORMATION}

A network of cGPS stations transects the Southern Alps, including sites on mountains immediately adjacent to Copland hot spring, and HAAS $100 \mathrm{~km}$ to the south-west (Fig. 1). Contemporary deformation is dominated by deep-seated slip on the Alpine Fault and locking from depths shallower than approximately $13-18 \mathrm{~km}$ (see also Beavan et al. 2007; Wallace et al. 2007). During the Mw7.8 Dusky Sound earthquake, there were clear offsets 
(A)

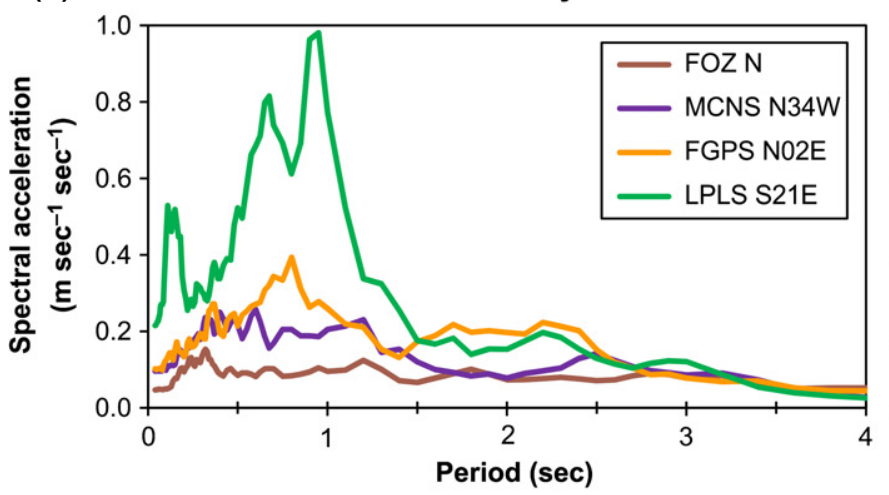

(C)

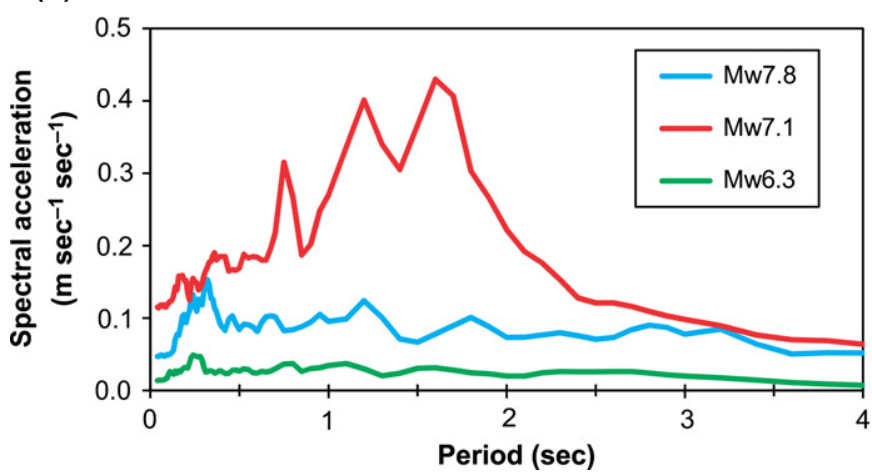

(B) Mw7.1 Darfield
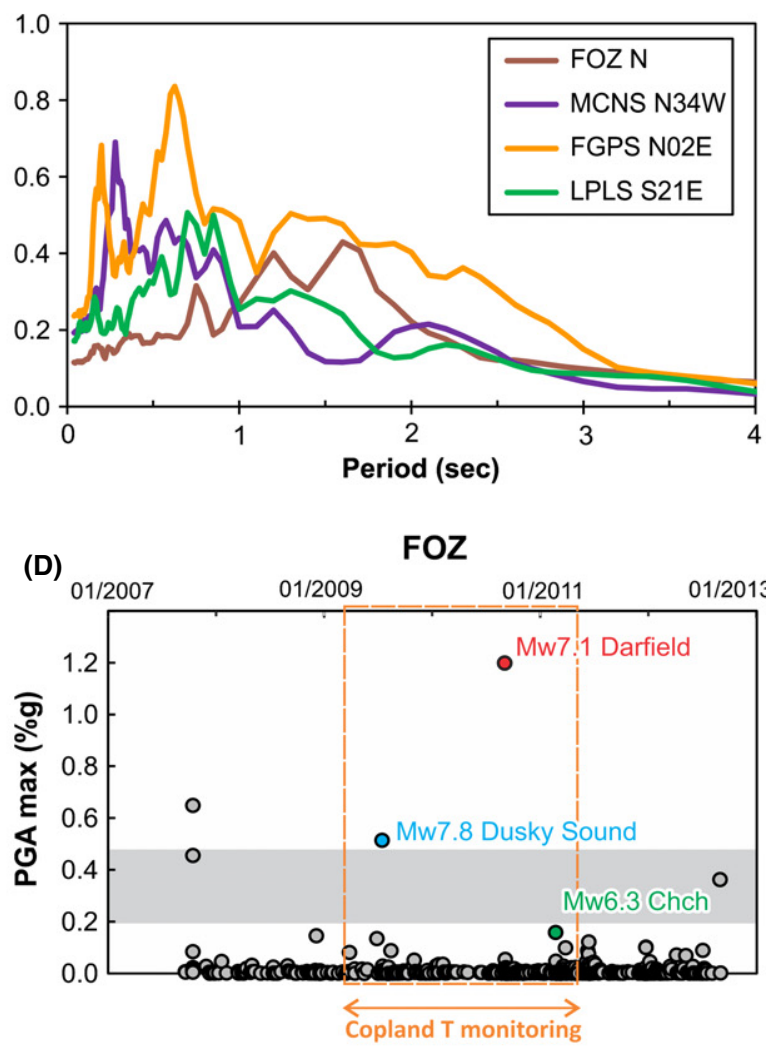

Fig. 9. Earthquake shaking recorded at seismometers FOZ, MCNS, FGPS and LPLS of the GeoNet national network. (A) Selected spectral accelerations measured during the Mw7.8 Dusky Sound earthquake, for comparison with (B) records of the same channels during the Mw7.1 Darfield earthquake. (C) Horizontal north-south spectral accelerations at FOZ during all three recent earthquakes. (D) A longer-term 5-year record of PGA max (\% g) at FOZ, marked with orange lines showing the period that Copland spring was monitored, and grey shading for possible threshold levels above which shaking produces a response at Copland hot spring.

of GPS station horizontal positions (easting or northing) ranging from 6 to $15 \mathrm{~mm}$ (Table 3 ; see also Supporting Information; Beavan et al. 2010a,b). These are similar to, but much smaller than, offsets for cGPS stations closer to the epicentre (Beavan et al. 2010b), yet are still significant above uncertainties at $95 \%(2 \sigma)$ confidence levels. Smaller offsets occurred during the Mw7.1 Darfield earthquake in 2010 , with eleven stations having horizontal offsets of 2 $8 \mathrm{~mm}$ that appear significant (Table 3 ). There were no discernable changes in the Southern Alps cGPS station positions (horizontal or vertical) as a result of the Mw6.3 Christchurch aftershock in February 2011. During the Mw7.8 Dusky Sound earthquake, the coseismic horizontal motion was consistently towards the south-west (Fig. 1B), deviating from long-term secular motion of South Island sites towards the north-west. South-west shifts are compatible with the direction of motions modelled for slip on the subduction interface beneath Fiordland during the Mw7.8 earthquake (Beavan et al. 2010b,c). In addition to horizontal shifts, there are clear earthquake-related changes in vertical position at the time of the earthquakes, albeit within a higher degree of uncertainty. Stations near Copland hot spring (VEXA, PILK, CNCL) decreased in elevation during the Mw7.8 Dusky Sound earthquake, but were surrounded by stations that decreased in elevation (Fig. 1B, Table 3). Most stations were uplifted during the Mw7.1 Darfield earthquake.

The earthquake-induced motions recorded by the cGPS stations are small and of a scale that would be impossible to confirm by campaign-style geodetic studies. By plotting the horizontal offsets versus distance across the GPS transect from the Alpine Fault, we obtain a sense of the regional variation, which shows some consistency between the Mw7.8 Dusky Sound and the Mw7.1 Darfield earthquakes on the western side of the Southern Alps (Fig. 10). In both the earthquakes, there are differences of at least $6 \mathrm{~mm}$ in the offsets over the $30-\mathrm{km}$ distance west of the Main Divide, with smallest offsets west of the Alpine Fault at QUAR. This indicates that both earthquakes induced small, permanent, dextral shear strains at amplitudes of between $10^{-7}$ and $10^{-6}$. There are also local differences in vertical shifts, a local aberration at PILK (Table 3 ), or 


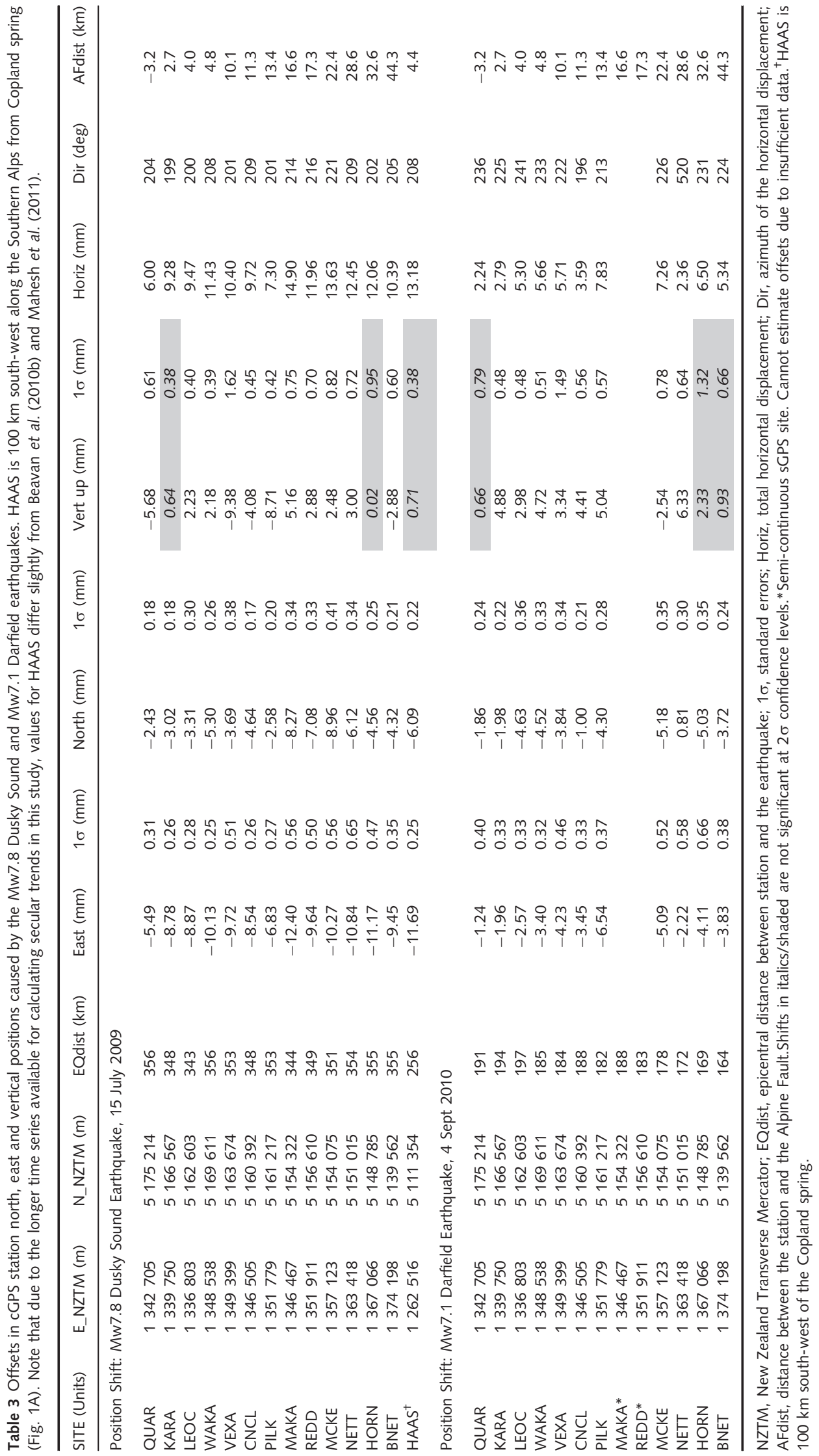




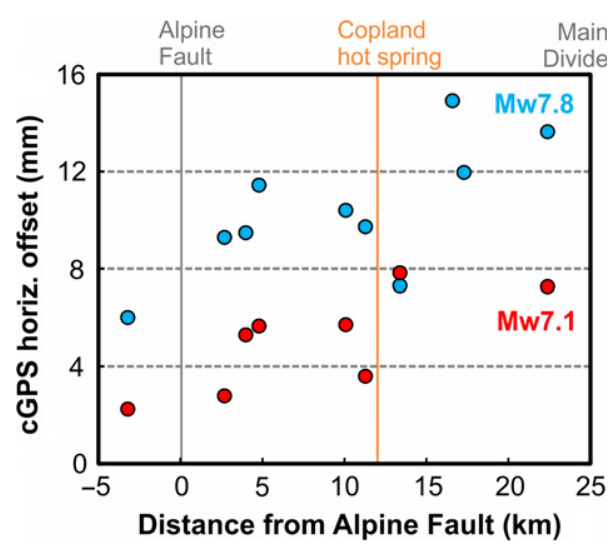

Fig. 10. Calculated cGPS station horizontal offsets (in $\mathrm{mm}$ ) during the Mw7.8 Dusky Sound (blue) and Mw7.1 Darfield (red) earthquakes, plotted against distance from the Alpine Fault in a transect south-eastwards across the Southern Alps a high angle to the displacement vectors (see Fig. 1B). The regional variation in horizontal offset reflects permanent dextral shear strains imparted by the earthquakes. Copland hot spring is situated in the centre of the transect, $12 \mathrm{~km}$ from the Alpine Fault.

differences in horizontal offsets in a NW-SE direction, which point at volumetric strains of a similar $\left(10^{-7}\right.$ to $10^{-6}$ ) magnitude along the Southern Alps. But given the strong alignment of the stations in a transect, with motions near the lower limits of resolution, we remain cautious not to over interpret these data. Importantly, we can be confident that both the earthquakes imparted permanent dextral strains of $10^{-7}$ to $10^{-6}$ through rocks in the vicinity of Copland hot spring, which are at the lower limit of strains where permeability changes have been previously demonstrated to occur (Elkhoury et al. 2006; Manga et al. 2012). Although dynamic strains associated with seismic waves may have been higher, it means there is no requirement to invoke mechanisms that operate without permanent strains, such as pore unblocking, to explain changes observed at the spring.

\section{DISCUSSION}

Hydrological changes associated with moderate to large earthquakes around the world have been compiled as a function of earthquake magnitude and epicentral distance and related to seismic energy density as a measure of the maximum energy available to do work at a given location during an earthquake (Wang \& Manga 2010a,b; Fig. 11). Relatively few studies have quantified earthquake-induced temperature changes in thermal springs and wells, although the phenomenon is long-recognised. Mogi et al. (1989) outlined temperature increases of approximately $1^{\circ} \mathrm{C}$ in a 600-m deep, cased, geothermal well on Izu Peninsula (Japan) following nearby $(<600 \mathrm{~km}$ distant) large earthquakes. These temperature changes, generally sharp rises in a steplike pattern with gentle linear cooling between seismic events, were interpreted to reflect increased flow rates in the well, which occurred once seismic energy density reached approximately $10^{-2} \mathrm{~J} \mathrm{~m}^{-3}$ (Wang \& Manga 2010b; see also Fig. 11). Other changes in thermal spring discharge, temperature or hydrochemistry have occurred at higher energy thresholds approximately $10^{-1} \mathrm{~J} \mathrm{~m}^{-3}$ (for streamflow) to approximately $1 \mathrm{~J} \mathrm{~m}^{-3}$ (for spring discharge) (e.g. King et al. 1994; Sato et al. 2000; Manga \& Rowland 2009; Liu et al. 2010; see Wang \& Manga $2010 a, b)$. Increased discharge, conductivity or ionic concentrations of springs and streams after earthquakes are usually attributed to changes in permeability and post-seismic release of deep fluids (e.g. Rojstaczer \& Wolf 1992; Sato et al. 2000; Favara et al. 2001). Observed thermal well and spring responses to earthquakes are most commonly opposite to the cooling and chemical dilution we describe at Copland hot spring (although see Howald et al. 2014).

Copland hot spring is derived from mixing of deep, upwelling, thermally heated meteoric water and a minor component of shallow, cool, infiltrating meteoric water. Our interpretation of the observed earthquake-related temperature and fluid chemistry responses is that shaking has altered the permeability structure of adjacent mountains or shallow crust, somehow opening or closing the aperture of fractures in schist bedrock. The earthquake-induced change in permeability alters the proportions of deep thermal to shallow meteoric water emerging at the surface, thereby creating a change in the $\mathrm{pH}$, conductivity and trace element chemistry of spring water and contributing to the cooling. From observations immediately at hand, however, we cannot be entirely certain whether there was an increase in permeability that allowed greater quantities of cool near-surface groundwater to be driven downwards by topographic head to mix with upwelling hot water, or a decrease in permeability at depth that restricted the amount of upwelling hot water. We infer the former to be more likely, supported by arguments below.

Of importance is that the present flow regime in the Southern Alps can be affected at relatively low shaking intensity, hundreds of kilometres from the epicentre of an earthquake. The observed earthquake-related responses at Copland spring occurred in association with shaking at peak ground accelerations that are very unlikely to have exceeded approximately $2 \% \mathrm{~g}$ during these earthquakes, corresponding to Modified Mercalli (MM) intensities of III-IV (weak to light) and seismic energy densities of approximately $10^{-1} \mathrm{~J} \mathrm{~m}^{-3}$ (Fig. 11). Observed responses occurred when shaking exceeded PGA approximately $0.5 \%$ $\mathrm{g}$ and dynamic stresses exceeded 0.05-0.1 MPa. There was an absence in a clear thermal response to the Mw6.3 Christchurch earthquake at seismic energy density approximately $10^{-2} \mathrm{~J} \mathrm{~m}^{-3}$. The threshold for response at Copland may be close to the approximately $10^{-2} \mathrm{~J} \mathrm{~m}^{-3}$ required 


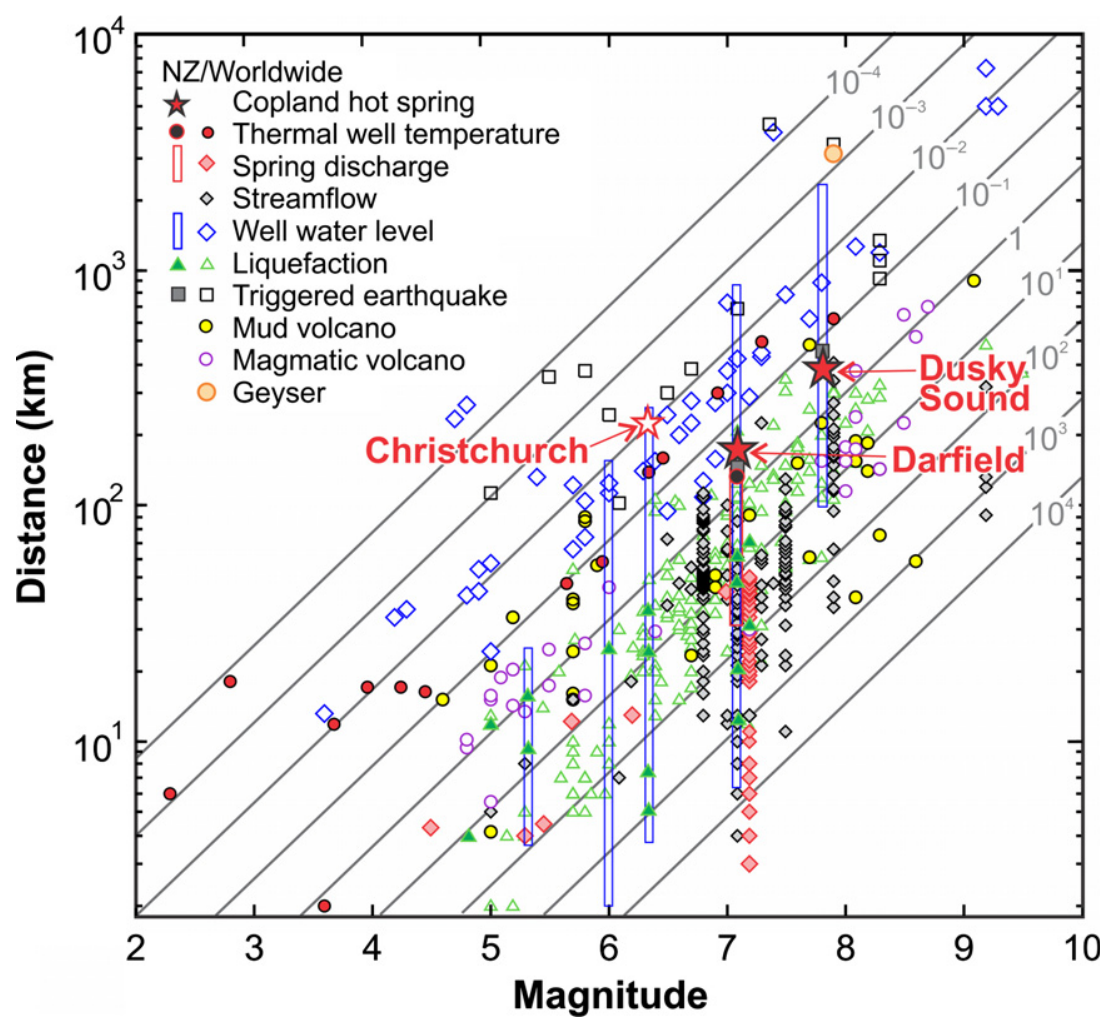

Fig. 11. The Mw7.8 Dusky Sound and Mw7.1 Darfield earthquake-induced changes at Copland hot spring (star symbols) on an earthquake magnitude versus distance plot showing worldwide earthquake-triggered hydrological changes collated by Wang \& Manga (2010a,b). Hydrological responses to New Zealand (NZ) earthquakes have been collated from Hancox et al. (2003), Cox et al. (2012b), Gulley et al. (2013) and Boese et al. (2014). The temperature change in Copland spring following the Mw6.3 Christchurch earthquake is plotted for reference, although the response was not definitive. Contours of constant seismic energy density follow Wang \& Manga (2010a,b), and thermal well temperature changes (Mogi et al. 1989) are distinguished from spring discharge changes (King et al. 1994; Sato et al. 2000; Manga \& Rowland 2009) that were not shown in the original figures of Wang \& Manga (2010a,b).

the artesian thermal well in Japan (Mogi et al. 1989) to respond (Fig. 11) and certainly lower than that recorded to produce changes in spring discharge elsewhere (King et al. 1994; Sato et al. 2000; Manga \& Rowland 2009; Fig. 11). Records from the nearby FOZ seismometer and the more comprehensive National Seismic Hazard Model (Stirling et al. 2002, 2012) suggest this level of shaking can be expected at every 1-10 years. Correspondingly, subtle changes in permeability can be expected on an annual to decadal time scale in the central Southern Alps.

\section{Temperature and chemistry constraints on hydrological flow models}

When guided by site surface observations, spring discharge measurement and the mapped thermal anomaly (Fig. 3), the spring water temperature and chemistry observations provide information on the subsurface geometry of the Copland spring hydrothermal system. The emergence of water with hot temperature at the surface requires flow to be confined to a relatively narrow pathway such that its flow rate is sufficient to retain heat advected from depth. The response time associated with rainfall-related cooling provides information about near-surface hydrology and heat exchange. The time lag of cooling onset and subsequent decay of temperature in response to earthquakes provides information about deeper hydrological change and heat exchange. Water chemistry observations confirm that cooling after earthquakes is associated with addition of cold meteoric fluids to the hydrothermal conduit.

Advected heat in the spring at the surface has an equivalent power of 1.4 MW, based on the total estimated flow rate $\left(7 \mathrm{~kg} \mathrm{sec}^{-1}\right.$ - includes main source vent and other small peripheral discharge seeps), the difference between spring temperature and ambient surface conditions $\left(50.4^{\circ} \mathrm{C}\right)$, and specific heat capacity of water. Spring water chemical analyses indicate that the deep fluid source equilibrated at temperatures of at least approximately $160^{\circ} \mathrm{C}$, which is estimated to be found at a depth of $L=2-3 \mathrm{~km}$ beneath the ground at this location, on the basis of modelled and measured geothermal gradients in the region (Allis et al. 1979; Koons 1987; Sutherland et al. 2012). The surface temperature is approximately $10^{\circ} \mathrm{C}$, so ambient conditions are approximately $150^{\circ} \mathrm{C}$ hotter at this depth. Fluid emerges at $56-58^{\circ} \mathrm{C}$, so about one-third of the heat 
is retained in the fluid and the rest must be conducted away laterally along its pathway to the surface. Flow from depth presumably occurs within a relatively porous, fractured zone in the schist.

Rain-related transient changes in temperature are rapid, responding and recovering in just a few hours. Finite difference models of a shallow reservoir that fills according to rain input and empties at a rate proportional to its fill height are able to explain the time lags and amplitudes of temperature change. The physical explanation is probably a combination of two factors: (i) dilution of spring water by near-surface groundwater from within the thin, underlying layer of alluvium and debris-flow sediment, including surface addition during times of particularly heavy rain (Fig. 2); and (ii) heat advection from the shallow thermal boundary layer around the hot spring during times of high near-surface cold-water flow through surface sediments. The rapid response reflects high near-surface permeability and very shallow depth of the processes $(<10 \mathrm{~m})$.

Water chemistry, conductivity, and $\mathrm{pH}$ measurements indicate earthquakes are associated with connection of cold-water input to the hot spring conduit at depth. Thermal responses to the Mw7.8 Dusky Sound and Mw7.1 Darfield earthquakes were delayed after arrival of seismic waves, by 180 and $140 \pm 15 \mathrm{~min}$, respectively. It is possible that there was a delay between earthquake shaking and connection of the new cold input, similar to the lag between triggered swarms of seismicity observed beneath the Main Divide (Boese et al. 2014). However, we assume that the primary reason for the delay of temperature change onset relates to the time it takes to drain existing fluids between the new input at depth and the surface. At discharge of $6 \pm 11 \mathrm{sec}^{-1}$, between 38 and $82 \mathrm{~m}^{3}$ of fluid was expelled during the 140 - to 180 -min delay. If the zone of fractured schist has porosity within the extremes of $10-25 \%$ and forms a conduit with cross-sectional area of between $1 \mathrm{~m}^{2}$ (the dimension of the vent pool) and $10 \mathrm{~m}^{2}$, the depth of intersection for the cold-water input will be in a range of $15-410 \mathrm{~m}$.

A small increase in temperature was observed following the Mw7.8 Dusky Sound earthquake. This might be explained by an increase in flow rate of the spring caused by an increase in permeability, allowing greater volumes of hot water to carry additional heat to the pool from within the fracture system at depth. Alternatively, it is possible that shaking increased $\mathrm{CO}_{2}$ exsolution or shaking released $\mathrm{CO}_{2}$ bubbles from fracture walls, resulting in an increased volume of gas and fluid rising to the surface, driving a greater flow rate, and hence an increased amount of heat supplied to the pool. The spring fluid and gas discharge rate was not continuously monitored.

We interpret the decay of temperature after an earthquake, which is approximately exponential, to reflect thermal capacitance of the rock within a thermal boundary layer in and around the hot spring conduit. The temperature decay has a time constant of about 2 days (see Supporting Information Fig. S2), and the temperature change was entirely accomplished over 5-8 days. Assuming that there is an instantaneous change in source water temperature caused by dilution by a new cold-water pathway, as indicated from chemistry results, and integrating the Mw7.8 Dusky Sound earthquake-induced change in temperature through time, we find the thermal capacitor of the rock absorbs $4400 \mathrm{MJ}$. We assume an instantaneous change in input temperature caused by a new mixing ratio at the start of the exponential decay; a constant input temperature at the base of the capacitor during the decay that is equal to the final equilibrated temperature; a flow rate of $7 \mathrm{~kg} \mathrm{sec}^{-1}$; and assume that the anomalous temperature of the fluid above the input temperature is derived from heat extracted from the capacitor. If the entire volume of the rock thermal buffer changed by the full $1^{\circ} \mathrm{C}$ temperature change, and assuming schist has specific heat capacity between 850 and $1000 \mathrm{~J} \mathrm{~kg}^{-1} \mathrm{~K}^{-1}$ and $2.67 \mathrm{~kg} \mathrm{~m}^{-3}$ density (Hatherton \& Leopard 1964), then a rock volume of $1500-2000 \mathrm{~m}^{3}$ is implied, although it is likely that some of the boundary layer changes by less. If we assume the cross-section area of the thermal boundary layer is similar to the surface elevated temperature anomaly area (Fig. 3), between 10 and $50 \mathrm{~m}^{2}$, then the depth of connection implied is in the range $30-200 \mathrm{~m}$. Whilst the values adopted are selected with ranges that are deliberately extreme, the result is consistent with the time delay calculation result. Importantly, their corroboration implies that the input of shallower meteoric water that produces the characteristic cooling is a shallow process, occurring in the uppermost few hundred metres of schist bedrock.

\section{Key observations and interpreted mechanism}

Although observations at Copland spring show that distal earthquakes can change the flow regime, fully connecting the field observations to mechanisms will require continuous monitoring of spring discharge, fluid chemistry and $\mathrm{CO}_{2}$ degassing. Some pertinent observations are as follows:

(1) Despite variable overprinting effects of rainfall, the Mw7.8 Dusky Sound and Mw7.1 Darfield earthquakes produced a characteristic style of temperature response.

(2) Cooling following the Mw7.1 Darfield earthquake occurred from a background temperature that was already (still) depressed, 14 months after the Mw7.8 Dusky Sound earthquake had affected the system. The causal mechanism was capable of stacking one cooling on top of the next - the system temperature, and by inference permeability, it did not need to fully recover before being influenced by another large earthquake.

(3) Earthquakes with quite different source characteristics (location, Mw, Me, direction) and resultant offsets 
recorded locally by cGPS, both produced small permanent dextral shear strains of $10^{-7}-10^{-6}$ and a similar characteristic response.

(4) Nearest seismographs recorded quite different spectral patterns during the Mw7.8 Dusky Sound and Mw7.1 Darfield earthquakes, so causal mechanisms are independent of shaking frequency.

(5) There are a number of similarities between observed earthquake-induced responses in Copland spring and nearby delayed-triggered microseismicity (Boese et al. 2014). Although no specific triggered swarms were noted in the vicinity of Copland valley, swarms occurred several hours after the earthquakes, lasting for approximately the same period it takes for Copland spring to adjust to a new cooler background temperature.

(6) The smaller Mw6.3 Christchurch earthquake produced either no response or at most a short-lived, small steplike temperature drop - despite having almost recovered to mid-2010 (pre-Mw7.1) background temperatures. Given the Mw7.1 Darfield earthquake had previously influenced the system's temperature without the need for recovery, we suggest the 5-month period between the Mw6.3 Christchurch and the Mw7.1 Darfield earthquakes and partial recovery would have been sufficient for a response to have occurred and been observed had the Mw6.3 shaking been sufficiently large. We therefore infer that seismic amplitude is important for disturbing the subsurface fluid flow in the Southern Alps. A shaking threshold at around PGA approximately $0.5 \% \mathrm{~g}$ and/or with dynamic stresses of 0.05-0.1 MPa and seismic energy density approximately $10^{-1} \mathrm{~J} \mathrm{~m}^{-3}$ needs to be met to produce a characteristic response at Copland hot spring.

(7) Partial recovery had occurred around l year after the Mw7.1 Darfield earthquake, but total recovery had yet to occur by December 2013. Recovery does not seem to be as linear/characteristic as cooling decays, but appears likely to occur at annual to decadal time scales. Variable recovery times might not be unexpected given the Mw7.8 Dusky Sound earthquake was the largest seismic event experienced in the South Island for about 80 years.

(8) There is some degree of stability of the hydrothermal system, such that the spring has maintained a temperature at approximately $56^{\circ} \mathrm{C}$ for nearly four decades (since Barnes et al. 1978). The spring was visited by Māori in pre-European time and has been present at the site for sufficient time for a large deposit of travertine calcite to precipitate.

It has been shown in a recent contribution outlining meteoric infiltration into mountains of crystalline rock in Fiordland (Fig. 1A), that permeability cannot be a simple function of depth (Upton \& Sutherland 2014). Instead, upper crustal permeability is modelled as a function of strength and the state of stress in the rock, which correlates with the proximity of the rock mass to brittle failure criteria (see also Townend \& Zoback 2000; Zoback 2010). Topography creates spatial heterogeneities in the proximity to failure that extend to depths similar to the height of adjacent mountains. The study proposes three processes that load the rock mass to failure and hence create permeability: long-term regional tectonic loading; short-term transient loading during phenomena such as earthquakes; and topography. Following this conceptual framework, we suspect that active deformation and topography must have an important influence on the processes observed in Copland spring and propose the setting of the Southern Alps in the hanging wall of the Alpine Fault may be particularly sensitive to influences such as distal earthquakes. The notion that tectonic and hydrogeological setting could be an important factor in determining the scale of groundwater response to distal earthquakes, with greater changes occurring at stress-sensitive sites, has also been proposed on the basis of continental-scale observations in China by Shi et al. (2014).

The central Southern Alps region is a locus for contemporary deformation, with geodetic-determined shear strain rates $>0.3 \mathrm{ppm} \mathrm{a}^{-1}$ and maximum uplift rate $10-20 \mathrm{~km}$ south-east of the Alpine Fault (Wallace et al. 2007; Beavan et al. 2010a). The contemporary deformation, however, does not correspond with the long-term (geologic) pattern of rock exhumation and deformation, in which the most strongly-deformed, highest-metamorphic grade mylonite and schist have been most recently exhumed immediately beside Alpine Fault at rates around $10^{-2} \mathrm{~m} \mathrm{a}^{-1}$ (Little et al. 2005; Herman et al. 2009). Observed contemporary deformation in the upper crust is therefore thought to be largely elastic and expected to be released when the Alpine Fault next ruptures (Ellis et al. 2006; Beavan et al. 2007). The rapidly uplifting mountains appear to be in a state of incipient gravitational (Allen et al. 2011) as well tectonic failure, such that over multiple-earthquake timescales, there is a balance between uplift and erosion. Landslides, rockfalls and erosion presently generate annual suspended-sediment yields in the rivers that are amongst the highest in the world and broadly match long-term $10^{-2} \mathrm{~m} \cdot \mathrm{a}^{-1}$ rates of exhumation (see Hicks et al. 1996; Cox \& Sutherland 2007; and refs therein). The central Southern Alps should be considered to be in a state of tectonic and topographic criticality (Koons 1994), or near-criticality, such that shaking at relatively low thresholds is potentially capable of generating perturbations to shallow fluid circulation.

GPS monitoring showed that earthquakes induced permanent shear strains of $10^{-7}$ to $10^{-6}$ across the Southern Alps, and potentially local volumetric strains of a similar magnitude, that are towards the lower limits of resolution. Given the rate and state of elastic strain accumulation, it is conceiv- 
able that the passage of seismic waves could have triggered the release of stored elastic deformation or perturbed the topographic stress state, thereby contributing to the motions and strain recorded by the GPS network. It may imply the local ambient stress state of the rock mass is important in the evolution of permeability and hydrological responses at intermediate- and far-field distances, so therefore warrants further research. Given also that the Alpine Fault is late in a regular cycle of stress accumulation (Sutherland et al. 2007; Berryman et al. 2012), some form of rupture seems imminent and much may soon be learnt about the evolution of permeability and the flow regime in the Southern Alps.

Flow of fluid through tight schist rocks will be highly sensitive to small changes in the apertures of the fractures and connected networks. Based on the situation presented above, we suspect the passage of seismic waves exploits either topographic and/or stored tectonic stress to enhance permeability through the physical opening of fractures, or minor generation of new fractures, in the uppermost few kilometres. The strains are likely to be small at a regional scale, at least $10^{-7}$ or $10^{-6}$ as recorded by motion of the cGPS network, although locally could be potentially larger reflecting the presence of critically oriented fractures. Closure of the fracture network might then occur through the regional plate-tectonic-related strain, which accumulates at between $10^{-7}$ and $10^{-6} \mathrm{a}^{-1}$ in the Southern Alps so has potential to facilitate physical recovery within about 1-10 years.

The explanation of fracture opening, above, draws on the observation of permanent strain induced by the earthquakes. However, there are alternative explanations, or other physical and chemical mechanisms at Copland hot spring which could also contribute to observed responses and changes in permeability. For example, PGV values (Table 2) suggest the passage of seismic waves imparted dynamic stresses exceeding 0.05-0.10 $\mathrm{MPa}$, which might enable the fractures to become unclogged and/or held open by some form of chemical process, cleaned by an increase in turbidity, or poroelastic pressuring (Manga et al. 2012). Copland hot spring fluid, at least in the near surface, is a two-phase mixture in which $\mathrm{CO}_{2}$ bubbles are dispersed in suspending water. The $\mathrm{CO}_{2}$ bubbles potentially block channels through capillary forces, inhibiting the bulk flow and fluid mobility. So a change in the mobilisation or nucleation of gases by seismic waves could conceivably lead to an increase in bulk flow rate and an apparent increase in permeability. However, for such a mechanism to continue over periods of the observed responses at Copland spring, it would also need some form of sustained local disequilibrium through changes in temperature, fluid phase or invasion of new fluids, or allow flow that generates a poroelastic response that keeps fractures open for a sustained period. Based on evidence of prolonged, earthquake-induced, infiltration of cool, unexchanged, meteoric water into a fault-controlled geothermal system, Howald et al. (2014) suggested crustal-permeability changes can last much longer lived than previously thought $\left(>10^{3}\right.$ years $)$.

The rate of recovery of the flow regime at Copland, extending over years or even tens of years, is also consistent with the notion of effects limited by kinetics or diffusive mass transport. The spring actively exsolves $\mathrm{CO}_{2}$ and has deposited a travertine terrace at the surface. During upwelling, the drop in pressure causes $\mathrm{CO}_{2}$ to degas from the fluid, raising its $\mathrm{pH}$ and causing precipitation of calcite. Calcite is a common mineral phase within joint coatings, fault gouge and veins in the schist, with calcite precipitation inferred to have occurred at a range of depths in the subsurface (Koons et al. 1998; Boulton et al. 2014; Menzies et al. 2014). Recovery of the hydrothermal system following an earthquake could therefore involve a slow clogging of fractures and aperture closure by precipitation of calcite, rather than physical closure by accumulation of tectonicrelated stress.

Without monitoring the exact discharge and state of two-phase flow, we cannot fully decipher the interplay of chemical and physical processes to conclusively elucidate the causal mechanism(s). However, the hydrothermal flow regime was clearly perturbed, and observations at Copland spring provide some fresh insight. Observations of Copland spring responses also correspond with observations of nearby-triggered seismicity (Boese et al. 2014), so we propose the transient permeability is a function of stress and strength of the rock (Upton \& Sutherland 2014), and proportional to the proximity of failure. Copland spring provides empirical evidence that mountains at active plate boundaries are susceptible to infiltration, advection of heat and transient changes in permeability.

\section{SUMMARY \& CONCLUSIONS}

Thermal springs in the Southern Alps, New Zealand, originate through deep penetration of meteoric fluids into a thermal anomaly generated by rapid uplift and exhumation in the hanging wall of the Alpine Fault. The Copland hot spring $(-43.629 \mathrm{~S}, 169.946 \mathrm{E})$ is one of the most vigorously flowing of the springs, discharging strongly effervescent $\mathrm{CO}_{2}$-rich water at $6 \pm 11 \mathrm{sec}^{-1}$. Rainfall, air and vent water temperatures were continuously monitored at 15-min intervals from March 2009 to July 2011. The spring fluctuated at background values between 56 and $58^{\circ} \mathrm{C}$, with minor diurnal variation, but fell dramatically to approximately $40^{\circ} \mathrm{C}$ during heavy rainfall when deep upwelling fluids are diluted near surface by cool meteoric water. Recovery to background temperatures typically took 3-5 h after rain stopped falling, depending on the rainstorm magnitude. Smaller, but more sustained temperature decreases occurred in response to shaking from distal 
earthquakes. The Mw7.8 Dusky Sound (Fiordland) earthquake on 15 July 2009, centred $350 \mathrm{~km}$ south-west of the Copland spring, produced weak to light shaking intensities in the area (approximately MM III-IV) and low PGAs $(0.4-2.3 \% \mathrm{~g})$ at nearby seismographs and horizontal south-west displacements of 6-12 $\mathrm{mm}$ at cGPS stations nearby. After $180 \pm 15 \mathrm{~min}$ delay, the spring showed a warming of $0.20 \pm 0.05^{\circ} \mathrm{C}$, followed by a $0.9 \pm 0.2^{\circ} \mathrm{C}$ cooling over a 5-day period. Temperature remained depressed until the Mw7.1 Darfield (Canterbury) earthquake on 4 September 2010 , centred $180 \mathrm{~km}$ east of Copland spring, when shaking at approximately MMIV (light) intensities and PGA $0.5-2.8 \% \mathrm{~g}$ resulted in a further $1.1 \pm 0.2^{\circ} \mathrm{C}$ cooling delayed $140 \pm 15 \mathrm{~min}$ after the earthquake. Comparison of the temperature responses suggests they followed a characteristic cooling that did not require recovery between earthquakes and perhaps that similar features were activated by the ground motion. Shaking during the Mw6.3 Christchurch aftershock on 22 February 2011 was mostly $<0.5 \% \mathrm{~g}$ at nearby seismographs and was unable to produce the same response, but possibly induced a $0.36 \pm 0.05^{\circ} \mathrm{C}$ cooling masked behind effects of rainfall.

The Copland hot spring appears to respond characteristically to distal (intermediate-field) large earthquakes once shaking at PGA approximately $0.5 \% \mathrm{~g}$ and/or a dynamic stress threshold of approximately $0.05-0.10 \mathrm{MPa}$ has been overcome, following an exponential temperature decay that is quite distinct from more rapid rainfall-related cooling. The passage of seismic waves, even at low MMIII-IV shaking intensities, PGA $<2 \% \mathrm{~g}$ and seismic energy density around approximately $10^{-1} \mathrm{~J} \mathrm{~m}^{-3}$, can affect spring temperature, producing responses independent of variations in spectral frequency. Cooling at Copland spring was accompanied by a fluid $\mathrm{pH}$ increase and electrical conductivity decrease, reflecting a change in the mixture of deep-circulated hydrothermal meteoric fluid and shallow-circulating meteoric fluid. cGPS stations indicate Mw7.8 Dusky Sound and Mw7.1 Darfield earthquakes caused permanent shifts with motion near the lower limits of detection, which were sufficient to induce static strains of $10^{-7}$ to $10^{-6}$ across the central Southern Alps. Such shaking thresholds will be exceeded and potentially affect the hydrothermal flow regime at annual to decadal timescales.

Deciphering the exact mechanisms responsible for Copland spring response to earthquakes has been hampered by not knowing the exact discharge of the hot spring through time. We infer the temperature and hydrochemical responses reflect subtle earthquake-induced changes in the $10^{-15}-10^{-12} \mathrm{~m}^{2}$ fracture permeability of schist mountains adjacent to the spring, allowing greater quantities of cool near-surface groundwater to mix with upwelling hot water. Our favoured mechanism is a physical opening or generation of new fractures in the uppermost few hundred metres of the schist bedrock, perhaps later closing under gradual readjustment to regional stress, but there is potential for combined physical-chemical mechanisms to play a role in the process, particularly the deposition of calcite during post-earthquake recovery. We propose that active deformation, tectonic and topographic stress make the hanging wall of the Alpine Fault particularly susceptible to earthquake-induced transient permeability changes.

\section{ACKNOWLEDGEMENTS}

Samples from the Westland National Park were collected under Department of Conservation permit WC-22994GEO. This project was funded under GNS Science's 'Impacts of Global Plate Tectonics in and around New Zealand Programme' (PGST Contract C05X0203). Geochemical analyses were funded by a Natural Environmental Research Council-CASE PhD studentship award NE/ G524160/1 to CDM (GNS Science CASE Partner) and NERC grants NE/H012842/1, NE/J024449/1 and IP1187-0510 to DAHT. We acknowledge the New Zealand GeoNet project and its sponsors EQC, GNS Science and LINZ, as well as the late John Beavan, for providing data used in this study. We wish to thank our colleagues John Townend, Jim Cousins, John Haines, Carolin Boese, Rachael James, Dave Craw, Delia Strong and Agnes Reyes for discussions and helpful comments, although not necessarily implying they agree with all of our interpretations and conclusions.

\section{REFERENCES}

Allen SK, Cox SC, Owens IF (2011) Rock avalanches and other landslides in the central Southern Alps of New Zealand: a regional study considering possible climate change impacts. Landslides, 8, 33-48.

Allis RG, Shi Y (1995) New insights to temperature and pressure beneath the central Southern Alps, New Zealand. New Zealand Journal of Geology and Geophysics, 38, 585-92.

Allis RG, Henley RW, Carman AF (1979) The thermal regime beneath the Southern Alps. In: The origin of the Southern Alps. Bulletin of the Royal Society of New Zealand, Vol. 18 (eds Walcott RI, Cresswell MM), pp. 79-85. Royal Society of New Zealand, Wellington.

Barnes I, Downes CJ, Hulston JR (1978) Warm springs, South Island, New Zealand, and their potential to yield laumontite. American Journal of Science, 278, 1412-27.

Beavan RJ, Ellis SM, Wallace LM, Denys P (2007) Kinematic constraints from GPS on oblique convergence of the Pacific and Australian Plates, central South Island, New Zealand. In: $A$ Continental Plate Boundary: Tectonics at South Island, New Zealand. Geophysical Monograph, 175 (eds Okaya DA, Stern TA, Davey FJ), pp. 75-94. American Geophysical Union, Washington, DC.

Beavan RJ, Denys P, Denham M, Hager B, Herring T, Molnar P (2010a) Distribution of present-day vertical deformation across the Southern Alps, New Zealand, from 10 years of GPS data. Geophysical Research Letters, 37, L16305. 
Beavan RJ, Samsonov S, Denys P, Sutherland R, Palmer NG, Denham M (2010b) Oblique slip on the Puysegur subduction interface in the 2009 July Mw7.8 Dusky Sound earthquake from GPS and InSAR observations: implications for the tectonics of southwestern New Zealand. Geophysical Journal International, 183, 1265-86.

Beavan RJ, Samsonov S, Motagh M, Wallace L, Ellis S, Palmer NG (2010c) The Darfield (Canterbury) earthquake: geodetic observations and preliminary source model. Bulletin of the New Zealand Society for Earthquake Engineering, 43, 228-35.

Beavan RJ, Fielding E, Motagh M, Samsonov S, Donnelly N (2011) Fault location and slip distribution of the 22 February 2011 Mw6.2 Christchurch, New Zealand, earthquake from geodetic data. Seismological Research Letters, 82, 789-99.

Berryman KR, Cochran UA, Clark KJ, Biasi GP, Langridge RM, Villamor P (2012) Major earthquakes occur regularly on an isolated plate boundary fault. Science, 336, 1690-3.

Boese C, Townend J, Smith EGC, Stern TA (2012) Microseismicity and stress in the vicinity of the Alpine Fault, central Southern Alps, New Zealand. Journal of Geophysical Research, 117, B02302.

Boese CM, Stern TA, Townend J, Bourguignon S, Sheehan A, Smith EGC (2013) Sub-crustal earthquakes within the Australia-Pacific plate boundary zone beneath the Southern Alps, New Zealand. Earth and Planetary Science Letters, 376, 212-19.

Boese C, Jacobs K, Smith EGC, Stern TA, Townend J (2014) Background and delayed-triggered swarms in the central Southern Alps, South Island, New Zealand. Geochemistry, Geophysics, Geosystems, 15, 945-64.

Boulton C, Moore DE, Lockner DA, Toy VG, Townend J, Sutherland R (2014) Frictional properties of exhumed fault gouges in DFDP-1 cores, Alpine Fault, New Zealand. Geophysical Research Letters, 41, 356-62.

Bradley BA, Cubrinovski M (2011) Near-source strong ground motions observed in the 22 February 2011 Christchurch earthquake. Seismological Research Letters, 82, 853-65.

Brodsky EE, Karakostas V, Kanamori H (2000) A new observation of dynamically triggered regional seismicity: earthquakes in Greece following the August, 1999 Izmit, Turkey earthquake. Geophysical Research Letters, 27, 2741-4.

Brodsky EE, Roeloffs E, Woodcock D, Gall I, Manga M (2003) A mechanism for sustained groundwater pressure changes induced by distant earthquakes. Journal of Geophysical Research-Solid Earth, 108, 2390.

Cousins WJ, McVerry GH (2010) Overview of strong-motion data from the Darfield earthquake. Bulletin of the New Zealand Society for Earthquake Engineering, 43, 222-7.

Cox SC, Barrell DJA (2007) Geology of the Aoraki area: scale 1:250,000. Institute of Geological \& Nuclear Sciences 1:250,000 geological map 15. Lower Hutt, GNS Science. 71 pages +1 folded map. ISBN 0478099622.

Cox SC, Sutherland R (2007) Regional geological framework of South Island, New Zealand, and its significance for understanding the active plate boundary. In: A continental Plate Boundary: Tectonics at South Island, New Zealand. Geophysical Monograph, 175 (eds Okaya DA, Stern TA, Davey FJ), pp. 1946. American Geophysical Union, Washington, DC.

Cox SC, Craw D, Chamberlain CP (1997) Structure and fluid migration in a late Cenozoic duplex system forming the Main Divide in the central Southern Alps, New Zealand. New Zealand Journal of Geology and Geophysics, 40, 359-73.

Cox SC, Song SH, White PA, Davidson P, Strong DT (2010) The Canterbury and other earthquakes: far field effects on groundwater. In: Water: The Blue Gold. Proceedings of the New Zealand Hydrological Society Conference 2010, 7-10 December, p. 175-6. University of Otago, Dunedin. Wellington, New Zealand Hydrological Society.

Cox SC, Stirling MW, Herman F, Gerstenberger M, Ristau J (2012a) Potentially active faults in the rapidly eroding landscape adjacent to the Alpine Fault, central Southern Alps, New Zealand. Tectonics, 31, TC2011.

Cox SC, Rutter HK, Sims A, Manga M, Wier JJ, Ezzy T, White PA, Horton TW, Scott D (2012b) Hydrological effects of the Mw7.1 Darfield (Canterbury) earthquake, 4 September 2010, New Zealand. New Zealand Journal of Geology and Geophysics, 55, 231-47.

DeMets C, Gordon RG, Argus DF (2010) Geologically current plate motions. Geophysical Journal International, 181, 1-80.

Domenco PA, Swartz FW (1990) Physical and Chemical Hydrogeology. John Wiley \& Sons, New York, pp. 824.

Dowrick DJ (1996) The modified Mercalli earthquake intensity scale; revisions arising from recent studies of New Zealand earthquakes. Bulletin of the New Zealand National Society for Earthquake Engineering, 29, 92-106.

Elkhoury JE, Brodsky EE, Agnew DC (2006) Seismic waves increase permeability. Nature, 441, 1135-8.

Elkhoury JE, Niemeijer A, Brodsky EE, Marone C (2011) Laboratory observations of permeability enhancement by fluid pressure oscillation of in-situ fractured rock. Journal of Geophysical Research, 116, B02311.

Ellis S, Beavan J, Eberhart-Phillips D, Stöckhert B (2006) Simplified models of the Alpine Fault seismic cycle: stress transfer in the mid-crust. Geophysical Journal International, $166,386-402$.

Faulkner DR, Jackson CAL, Lunn RJ, Schlische RW, Shipton ZK, Wibberley CAJ, Withjack MO (2010) A review of recent developments concerning structure, mechanics and fluid flow properties of fault zones. Journal of Structural Geology, 32, 1557-75.

Favara R, Grassa F, Inguaggiato S, Valenza M (2001) Hydrogeochemistry and stable isotopes of thermal springs: earthquake-related chemical changes along Belice Fault (Western Sicily). Applied Geochemistry, 16, 1-17.

Freeze RA, Cherry JA (1979) Groundwater. Prentice-Hall, Englewood Cliffs, NJ, pp. 604.

Fry B, Bannister SC, Beavan RJ, Bland L, Bradley BA, Cox SC, Cousins WJ, Gale NH, Hancox GT, Holden C, Jongens R, Power WL, Prasetya G, Reyners ME, Ristau J, Robinson R, Samsonov S, Wilson KJ, team G (2010) The Mw 7.6 Dusky Sound earthquake of 2009: preliminary report. Bulletin of the New Zealand Society for Earthquake Engineering, 43, 24-40.

GeoNet (2014) Earthquake strong motion data and processing. http://info.geonet.org.nz/display/appdata/

Strong-Motion+Data, accessed 15 February 2014.

Giggenbach WF (1988) Geothermal solute equilibria. Derivation of Na-K-Mg-Ca geoindicators. Geochimica et Cosmochimica Acta, 52, 2749-65.

Giggenbach WF, Sano Y, Wakita H (1993) Isotopic composition of helium, and $\mathrm{CO}_{2}$ and $\mathrm{CH}_{4}$ contents in gases produced along the New Zealand part of a convergent plate boundary. Geochimica et Cosmochimica Acta, 57, 3427-55.

Gledhill KR, Ristau J, Reyners ME, Fry B, Holden C (2011) The Darfield (Canterbury, New Zealand) Mw7.1 earthquake of September 2010: a preliminary seismological report. Seismological Research Letters, 82, 378-86.

Gulley AK, Ward NFD, Cox SC, Kaipio JP (2013) Groundwater responses to the recent Canterbury earthquakes: a comparison. Journal of Hydrology, 504, 171-81. 
Hancox GT, Cox SC, Turnbull IM, Crozier MJ (2003) Reconnaissance studies of landslides and other ground damage caused by the Mw7.2 Fiordland earthquake of 22 August 2003. Lower Hutt, Institute of Geological \& Nuclear Sciences Limited. GNS Science Science Report 2003/30. 32 p. ISBN 0478-0926-x.

Hatherton T, Leopard AE (1964) The densities of New Zealand rocks. New Zealand Journal of Geology and Geophysics, 7, 60525 .

Herman F, Cox SC, Kamp PJJ (2009) Low-temperature thermochronology and thermokinematic modelling of deformation, exhumation, and development of topography in the central Southern Alps, New Zealand. Tectonics, 28, TC5011.

Hicks DD, Hill J, Shankar U (1996) Variation of suspended sediment yields around New Zealand: the relative importance of rainfall and geology. International Association of Hydrological Sciences Publication No 236, 149-156. ISBN 0-947571-89-2.

Hill DP, Reasenberg PA, Michael A, Arabaz WJ, Beroza G, Brumbaugh D, Brune JN, Castro R, Davis S, Depolo D, Ellsworth WL, Gomberg J, Harmsen S, House L, Jackson SM, Johnston MJS, Jones L, Keller R, Malone S, Munguia L, Nava S, Pechmann JC, Sanford A, Simpson RW, Smith RB, Stark M, Stickney M, Vidal A, Walter S, Wong V, Zollweg J (1993) Seismicity remotely triggered by the magnitude 7.3 Landers, California, earthquake. Science, 260, 1617-23.

Howald T, Person M, Cambell A, Leuth V, Hofstra A, Sweetkind D, Gable C, Banerjee A, Luijendijk E, Crossey L, Karlstron K, Kelley S, Phillips F (2014) Evidence for long-time scale $\left(>10^{3}\right.$ years $)$ changes in hydrothermal activity induced by seismic events. Geofluids, (in this issue).

Howarth JD, Fitzsimons SJ, Norris RJ, Jacobsen GE (2012) Lake sediments record cycles of sediment flux driven by large earthquakes on the Alpine fault, New Zealand. Geology, 40, $1091-4$.

Husen S, Wiemer S, Smith RB (2004) Remotely triggered seismicity in the Yellowstone National Park region by the 2002 Mw7.9 Denali fault earthquake, Alaska. Bulletin of the Seismological Society of America, 94, S317-31.

Kaiser AE, Holden C, Beavan RJ, Beetham RD, Benites RA, Celentano A, Collet D, Cousins WJ, Cubrinovski M, Dellow GD, Denys P, Fielding E, Fry B, Gerstenberger MC, Langridge RM, Massey CI, Motagh M, Pondard N, McVerry GH, Ristau J, Stirling MW, Thomas J, Uma SR, Zhao JX (2012) The Mw 6.2 Christchurch Earthquake of February 2011: preliminary report. New Zealand Journal of Geology and Geophysics, 55, 6790.

King CY, Basler D, Presser TS, Evans WC, White LD, Minissale A (1994) In search of earthquake-related chemical changes along the Hayward Fault. Applied Geochemistry, 9, 83-91.

Koons PO (1987) Some thermal and mechanical consequences of rapid uplift: an example from the Southern Alps, New Zealand. Earth and Planetary Science Letters, 86, 307-19.

Koons PO (1989) The topographic evolution of collisional mountain belts: a numerical look at the Southern Alps, New Zealand. American Journal of Science, 289, 1041-69.

Koons PO (1994) Three-dimensional critical wedges: tectonics and topography in oblique collisional zones. Journal of Geophysical Research, 99, 12301-5.

Koons PO, Craw D (1991) Evolution of fluid driving forces and composition within collisional orogens. Geophysical Research Letters, 18, 935-8.

Koons PO, Craw D, Cox SC, Upton P, Templeton AS, Chamberlain CP (1998) Fluid flow during active oblique convergence: a Southern Alps model from mechanical and geochemical observations. Geology, 26, 159-62.

Koons PO, Norris RJ, Craw D, Cooper AF (2003) Influence of exhumation on the structural evolution of transpressional plate boundaries: an example from the Southern Alps, New Zealand. Geology, 31, 3-6.

Litchfield NJ, Van DR, Sutherland R, Barnes PM, Cox SC, Norris RJ, Beavan RJ, Langridge RM, Villamor P, Berryman KR, Stirling MW, Nicol A, Nodder SD, Lamarche G, Barrell DJA, Pettinga JR, Little TA, Pondard N, Clark KJ (2013) A model of active faulting in New Zealand. New Zealand Journal of Geology and Geophysics, 57, 32-56.

Little TA, Cox SC, Vry JK, Batt G (2005) Variations in exhumation level and uplift rate along the oblique-slip Alpine Fault, central Southern Alps, New Zealand. Geological Society of America Bulletin, 117, 707-23.

Liu WQ, Manga M (2009) Changes in permeability caused by dynamic stresses in fractured sandstone. Geophysical Research Letters, 36, L20307.

Liu WQ, Wang CH, Hwang LS (2010) Temporal variation of seepage water chemistry before and after the Hengchun Ms 7.2 earthquake in south Taiwan. Geoderma, 155, 107-14.

Mahesh P, Kundu B, Catherine JK, Gahalaut VK (2011) Anatomy of the 2009 Fiordland earthquake (Mw7.8), South Island, New Zealand. Geoscience Frontiers, 2, 17-22.

Manga M, Rowland JC (2009) Response of Alum Rock springs to the October 30, 2007 Alum Rock earthquake and implications for the origin of increased discharge after earthquakes. Geofluids, 9, 237-50.

Manga M, Beresnev I, Brodsky EE, Elkhoury JE, Elsworth D, Ingebritsen SE, Mays DC, Wang CY (2012) Changes in permeability caused by transient stresses: field observations, experiments, and mechanisms. Reviews in Geophysics, 50, RG2004.

Menzies CD (2012) Fluid Flow Associated with the Alpine Fault, South Island, New Zealand. Unpublished Ph.D thesis, University of Southampton. pp. 477.

Menzies CD, Teagle DAH, Craw D, Cox SC, Boyce AJ, Barrie D (2014) Incursion of meteoric waters into the ductile regime in an active orogen. Earth and Planetary Science Letters, 399, 114

Mogi K, Mochizuki H, Kurokawa Y (1989) Temperature-changes in an artesian spring at Usami in the Izu Peninsula (Japan) and their relation to earthquakes. Tectonophysics, 159, 95-108.

Montgomery DR, Manga M (2003) Streamflow and water well responses to earthquakes. Science, 300, 2047-9.

Mortimer N (1993) Jurassic tectonic history of the Otago schist, New Zealand. Tectonics, 12, 237-44.

Norris RJ, Cooper AF (2001) Late Quaternary slip rates and their significance for slip partitioning on the Alpine Fault, New Zealand. Journal of Structural Geology, 23, 507-20.

Orense RP, Kiyota T, Yamada S, Cubrinovski M, Hosono Y, Okamura M, Yasuda S (2011) Comparison of liquefaction features observed during the 2010 and 2011 Canterbury earthquakes. Seismological Research Letters, 82, 905-18.

Quigley M, Van DR, Villamor P, Litchfield NJ, Barrell DJA, Furlong K, Stahl T, Duffy B, Bilderback E, Noble D, Townsend DB, Begg JG, Jongens R, Ries W, Claridge J, Klahn A, Mackenzie H, Smith A, Hornblow S, Nicol R, Cox SC, Langridge RM, Pedley K (2010) Surface rupture of the Greendale Fault during the Darfield (Canterbury) Earthquake, New Zealand: initial findings. Bulletin of the New Zealand Society for Earthquake Engineering, 43, 236-42. 
Quigley M, Van DR, Litchfield NJ, Villamor P, Duffy B, Barrell DJA, Furlong K, Stahl T, Bilderback E, Noble D (2012) Surface rupture during the 2010 Mw7.1 Darfield (Canterbury) earthquake: implications for fault rupture dynamics and seismichazard analysis. Geology, 40, 55-8.

Reyes AG, Christenson BW, Faure K (2010) Sources of solutes and heat in low-enthalpy mineral waters and their relation to tectonic setting, New Zealand. Journal of Volcanology and Geothermal Research, 192, 117-41.

Reyners ME (2009) Large subduction thrust earthquake shakes southern New Zealand. Eos, 90, 282.

Reyners ME (2011) Lessons from the destructive Mw6.3 Christchurch, New Zealand, earthquake. Seismological Research Letters, 82, 371-2.

Roeloffs EA (1996) Poroelastic techniques in the study of earthquake-related hydrologic phenomena. Advances in Geophysics, 37, 135-95.

Roeloffs EA (1998) Persistent water level changes in a well near Parkfield, California, due to local and distant earthquakes. Journal of Geophysical Research-Solid Earth, 103, 869-89.

Rojstaczer S, Wolf S (1992) Permeability changes associated with large earthquakes - an example from Loma-Preita, California. Geology, 20, 211-14.

Rojstaczer S, Wolf S, Michel R (1995) Permeability enhancement in the shallow crust as a cause of earthquake-induced hydrological changes. Nature, 373, 237-9.

Saffer DM (2014) The permeability of active subduction plate boundary faults. Geofluids, (in this issue).

Sato T, Sakai R, Furuya K, Kodama T (2000) Coseismic spring flow changes associated with the 1995 Kobe earthquake. Geophysical Research Letters, 27, 1219-22.

Shi Z, Wang G, Manga M, Wang CY (2014) Continental-scale water-level response to a large earthquake. Geofluids, (in this issue).

Sibson R (1981) A Brief Description of Natural Neighbor Interpolation. Chapter 2 in Interpolating Multivariate Data. John Wiley \& Sons, New York, pp. 21-36.

Sibson RH (2001) Seismogenic framework for hydrothermal transport and ore deposition. Society of Economic Geologists Reviews, 14, 25-50.

Standards New Zealand (2004) NZS1170.5:2004, Structural Design Actions, Part 5: Earthquake actions New Zealand.

Stirling MW, McVerry GH, Berryman KR (2002) A new seismic hazard model for New Zealand. Bulletin of the Seismological Society of America, 92, 1878-903.

Stirling MW, McVerry GH, Gerstenberger MC, Litchfield NJ, Van DR, Berryman KR, Barnes P, Wallace LM, Villamor P, Langridge RM, Lamarche G, Nodder S, Reyners ME, Bradley B, Rhoades DA, Smith WD, Nicol A, Pettinga J, Clark KJ, Jacobs K (2012) National seismic hazard model for New Zealand: 2010 update. Bulletin of the Seismological Society of America, 102, 1514-42.

Sutherland R, Berryman KR, Norris R (2006) Quaternary slip rate and geomorphology of the Alpine Fault: implications for kinematics and seismic hazard in southwest New Zealand. Geological Society of America Bulletin, 118, 464-74.

Sutherland R, Eberhart-Phillips D, Harris RA, Stern TA, Beavan RJ, Ellis SM, Henrys SA, Cox SC, Norris RJ, Berryman KR, Townend J, Bannister SC, Pettinga J, Leitner B, Wallace LM, Little TA, Cooper AF, Yetton M, Stirling MW (2007) Do great earthquakes occur on the Alpine Fault in central South Island, New Zealand? In: A continental plate boundary: tectonics at South Island, New Zealand. Geophysical monograph, 175 (eds
Okaya DA, Stern TA, Davey FJ), pp. 235-51. American Geophysical Union, Washington, DC.

Sutherland R, Toy VG, Townend J, Cox SC, Eccles JD, Faulkner DR, Prior DJ, Norris RJ, Mariani E, Boulton C, Carpenter BM, Menzies CD, Little TA, Hastings M, De PG, Langridge RM, Scott HR, Lindroos ZR, Fleming B, Kopf AJ (2012) Drilling reveals fluid control on architecture and rupture of the Alpine fault, New Zealand. Geology, 40, 1143-6.

Taira T, Silver PG, Niu F, Nadeau RM (2009) Remote triggering of fault-strength changes on the San Andreas fault at Parkfield. Nature, 461, 636-U677.

Tait A, Henderson R, Turner R, Zheng X (2006) Thin plate smoothing spline interpolation of daily rainfall for New Zealand using a climatological rainfall surface. International Journal of Climatology, 26, 2097-115.

Townend J, Zoback MD (2000) How faulting keeps earth's crust strong. Geology, 28, 399-402.

Townend J, Sherburn S, Arnold R, Boese C, Woods L (2012) Three-dimensional variations in present-day tectonic stress along the Australia-Pacific plate boundary in New Zealand. Earth and Planetary Science Letters, 353-354, 47-59.

Truesdell AH (1976) Summary of section III: geochemical techniques in exploration. Proceedings of the 2 nd U.N. Symposium on the Development and Use of Geothermal Resources, San Francisco 1975. Vol. I, U.S. Government Printing Office, Washington DC, pp. liii-1xxx.

Upton P, Sutherland R (2014) High permeability and low temperature correlates with proximity to brittle failure within mountains at an active tectonic boundary, Manapouri tunnel, Fiordland, New Zealand. Earth and Planetary Science Letters, 389, 176-87.

Wallace LM, Beavan RJ, McCaffrey R, Berryman KR, Denys P (2007) Balancing the plate motion budget in the South Island, New Zealand using GPS, geological and seismological data. Geophysical Journal International, 168, 332-52.

Wang CY, Manga M (2010a) Earthquakes and water. Lecture Notes in Earth Sciences, 114, 235.

Wang CY, Manga M (2010b) Hydrologic responses to earthquakes and a general metric. Geofluids, 10, 206-16.

Wang CY, Wang CH, Manga M (2004a) Coseismic release of water from mountains: evidence from the $1999(\mathrm{Mw}=7.5)$ Chi-Chi, Taiwan, earthquake. Geology, 32, 769-72.

Wang CY, Wang CH, Kuo CH (2004b) Temporal change in groundwater level following the $1999(\mathrm{Mw}=7.5)$ Chi-Chi earthquake, Taiwan. Geofluids, 4, 210-20.

Wang CY, Wang LP, Manga M, Wang CH, Chen CH (2013) Basin-scale transport of heat and fluid induced by earthquakes. Geophysical Research Letters, 40, 1-5.

Wells A, Yetton MD, Duncan RP, Stewart GH (1999) Prehistoric dates of the most recent Alpine fault earthquakes, New Zealand. Geology, 27, 995-8.

Wells NS, Clough TJ, Condron LM, Baisden WT, Harding JS, Dong Y, Lewis GD, Lear G (2013) Biogeochemistry and community ecology in a spring-fed urban river following a major earthquake. Environmental Pollution, 182, 190-200.

Zoback MD (2010) Reservoir Geomechanics. Cambridge University Press, Cambridge, pp. 449. ISBN: 9780521146197

\section{SUPPORTING INFORMATION}

Additional Supporting Information may be found in the online version of this article: 
Data S1. Schist permeability, Chemical methods, Seismic and Geodetic data, Thermal decay observations and model.

Figure S1. Decomposed time-series of easting, northing and height measurements at continuous GPS stations CNCL and KARA, plotted relative to their secular modes.

Figure S2. Temperature data from Copland hot spring following the Dusky Sound earthquake on Wednesday 15 July 2009 at 9:22 pm NZST (red line).
Table S1. Permeability and hydraulic conductivity data from Lugeon packer tests (PT), head response tests (HT) or other methods found in unpublished engineering and/ or consultancy reports for the Haast Schist Group, which encompasses both Alpine and Otago schists. 